\title{
Cumhuriyet Dönemi Sanayi Kentinin Biyografisi: Kırıkkale
}

\section{Biography of an Industrial Town of Republican Era: Kırıkale}

\author{
Koray ÖZCAN ${ }^{1} \oplus$ \\ ${ }^{1}$ Pamukkale Üniversitesi, Mimarlık ve Tasarım Fakültesi Şehir ve Bölge Planlama Bölümü, Denizli, Türkiye
}

ORCID: K.Ö. 0000-0002-1221-9224

\section{Öz}

Türkiye Cumhuriyeti'nin kuruluş sürecinde ulusal kalkınma çabalarının, kırsal ve kentsel yerleşmelerin mekânsal ve işlevsel gelişim sürecinde etkili olduğu bilinmektedir. Bu süreçte, kırsal bağlamda Cumhuriyet Köyü olarak tanımlanan ideal köyler kurulurken kentsel bağlamda ise Kırıkkale, Gölcük, Karabük, İskenderun, Batman gibi askeri ve stratejik yatırımlar odaklı ilk sanayi kentlerinin kurulduğu görülmektedir. Bu araştırmanın amacl; milli silah imalatında uzmanlaşmış askeri ve stratejik sanayi kenti olarak kurulan Kırıkkale kentinin, mekânsal, işlevsel ve demografik gelişim sürecinin, ilk kuruluşundan günümüze dek uzanan süreçte analiz edilmesidir. Bu çerçevede, araştırmanın yöntem kurgusu üç aşamadan oluşan bir süreç tasarımına dayandırılmıştır. Birinci aşama, Kırıkkale kentinin sosyal-kültürel ve mekânsal tarihine ilişkin olarak yazılı kaynaklardan elde edilen verilerin ayrıntıda değerlendirilmesidir. İkinci aşama, Kırıkkale kentinin nüfus gelişme eğilimlerine ilişkin istatistiki verilerin incelenerek, göç olgusu bağlamında Kırıkkale kenti üzerindeki mekânsal ve işlevsel etkilerinin yorumlanmasıdır. Üçüncü aşama ise mekânsal ve işlevsel analizlerden elde edilen veriler esas alınarak üretilen şemalar eşliğinde Kırıkkale kentinin tarihsel gelişim sürecinin tanımlanmasıdır. Bu araştırmanın sanayi yatııım kararlarının kentleşme süreci üzerindeki mekânsal, işlevsel ve demografik etkilerinin tartışımasına akademik bağlamda katkı koyacağı yanısıra kentleşme ve sanayileşme süreçleri arasındaki etkileşim bağlamında geleceğe dönük planlama kararları için Kırıkkale örneğinde analitik bir çerçeve sunacağı düşünülmektedir.

Anahtar kelimeler: Kırıkkale, Sanayi Kenti, Kent Biyografisi

\section{ABSTRACT}

It is known that national development efforts in the foundation process of the Republic of Turkey happened within the spatial organization and functional development processes of the settlements that took place both in urban and rural contexts. Thus, the effects of these policies in the rural context had been the design of new ideal villages called the Republican Villages (Cumhuriyet Köyü in Turkish), in order to regenerate and improve the agricultural production and also rural life. As for their reflections in the urban context, it can be said that it was founded in the early industrial towns like Kırıkkale, Gölcük, Karabük, İskenderun, Batman which were specialized in military and strategic industries which depended on weapon, steel and iron manufacturing.

The aim of this study is to analyze the development process of the spatialization, functionalisation and demographic changes of the city of Kırıkkale. The city of Kırıkkale was founded as an industrial town specialized in weapon manufacturing, which was improved with the development process of the city. The methodological framework of this study consists of three main stages. The first stage is assessing the data from written resources related to the sociospatial history of the city of Kırıkkale. The second stage is examining the statistical data about demographic trends of Kırıkkale, and also the interpretation of the migration phenomenon and its effects on the city of Kırıkkale in the spatial and functional contexts. The last stage is defining the historical development process of the city of Kırıkkale by using schemas which were prepared using the information of spatial and functional analyses.

It is considered that this study contributes to the academic context by discussing the spatial, functional and demographic effects of industrial investment decisions on urbanization processes. Also, it is thought that it presents an analytical framework for the Kırıkkale case, in terms of planning decisions and strategies for the future in the context of the interaction between the industrialization and urbanization processes

Keywords: Kırıkkale, Industrial Town, Urban Biography

Başvuru/Submitted: 09.09.2019 • Revizyon Talebi/Revision Requested: 11.09.2019 • Son Revizyon/Last Revision Received: 08.12 .2019 • Kabul/Accepted: 24.12.2019 - Online Yayın/Published Online: 20.04 .2020 


\section{EXTENDED ABSTRACT}

It is known that national development efforts in the foundation process of the Republic of Turkey happened within the spatial organization and functional development processes of the settlements that took place both in urban and rural contexts. Thus, the effects of these policies in the rural context had been the design of new ideal villages called the Republican Villages (Cumhuriyet Köyü in Turkish), in order to regenerate and improve the agricultural production and also rural life. As for their reflections in the urban context, it can be said that it was founded in the early industrial towns like Kırıkkale, Gölcük, Karabük, İskenderun, Batman which were specialized in military and strategic industries which depended on weapon, steel and iron manufacturing.

The aim of this study is to analyse the development process of the spatialization, functionalisation and demographic changes of the city of Kırıkkale. The city of Kırıkkale was founded as an industrial town specialized in weapon manufacturing which was improved with the development process of the city. These analyses are examined under 4 (four) headings including the city's spatial background, historical past, planning experiences and socio-cultural context.

The methodological framework of this study depends on a process including three stages. The first stage is the assessment of data which was gathered from written resources related with the socio-spatial history of the city of Kirıkkale. The second stage is the examination of the statistical data about the demographic trends of Kırıkale, and also the interpretation of the migration phenomenon and its effects on the city of Kirıkale in the spatial and functional context. The last stage is the definition of the historical development process of the city of Kirıkkale by using schemas which were prepared by depending on information from the spatial and functional analyses.

It is considered that this study contributes to the academic context by discussing the spatial, functional and demographic effects of industrial investment decisions on the urbanization processes. Also, it is thought that it presents an analytical framework for the Kirikkale case, in terms of planning decisions and strategies for the future in the context of the interaction between the industrialization and urbanization processes.

Consequently, the findings which were revealed from the spatial and functional analyses of the city of Kirıkkale are outlined below. At first, it can be stated that the spatial development process in Kırıkale began as a planned town by constructing the military industrial complex with logistical facilities including housing and social buildings. As for the following process, the city of Kirıkkale developed as an unplanned town without having social and cultural facilities. Also, its technical infrastructure was insufficient because of the over urbanization and rapid population growth with unexpected migration that depended on the interaction between industrialization and urbanization. Secondly, Kırıkkale as an industrial town, was established in 1925, without an origin of historical settlement and also developed by autonomous investment decisions. Then, the first spatial development plan for Kırıkkale city was prepared in 1948. In this respect, it can be said that Kirıkkale, which is one of the first planned towns of the early Republican period, has an important urban experience in the history of Turkish urban planning. Thirdly, it can be said that the planning experiences focused on the city of Kirıkkale lagged behind the current urban development dynamics such as spatial, functional and demographic indicators.

For this reason, it is stated that the urban growth of Kirıkkale city had been directed by revision plans due to unmanaged and not well-planned spatial, functional and also demographic development processes. And lastly, Kirıkkale had been opened to growth by the immigrants from different regions of Central Anatolia because of the employment opportunities in industry. So, it can be said that Kırıkkale developed as a multicultural town lacking urbanity awareness. 


\section{GíRiş}

Cumhuriyetin kuruluş sürecinde ulusal kalkınma çabalarına dönük olarak üretilen öncelikli sanayi politikalarının kırsal ve kentsel yerleşmelerin mekânsal kuruluş ve işlevsel gelişim süreci üzerinde etkili olduğu söylenebilir. $\mathrm{Bu}$ süreçte, gelecekte gereksinim duyulacak mal-ürünlerin üretimine yönelik sanayi yatırımlarının devlet eliyle geliştirilmesi için sanayi planları hazırlandığı̆, Teşvik-i Sanayi Kanunu ile mali teşvikler sağlandığı, Birinci İzmir İktisat Kongresi'nde ise özellikle stratejik sanayi yatırımlarının önem ve gerekliliğinin vurgulandığı anlaşılmaktadır (İnan, 1989; Tümertekin, 1959: 16-54).

Ulusal sanayileşme-kalkınma çabaları kapsamında 1936 ve 1939 tarihli Sanayi Planları ile kırsal düzeyde Cumhuriyet Köyü olarak adlandırılan ideal köylerin tasarlanması, kentsel düzeyde ise sektörel tabanlı yer seçimi kararları eşliğinde gerçekleştirilen stratejik öncelikli sanayi yatırımları ile erken sanayi kentlerinin kurulduğu-geliştirildiği görülür (İnan, 1972; İnan, 1973). Bu çerçevede bakılırsa, sanayi yatırımları odaklı yer seçimi kararları ile işçi yerleşkeleri olarak kurularak, süreç içinde kentsel yerleşmelere dönüşen deniz harp sanayisi için Gölcük (1925), kara harp sanayisi için Kırıkkale (1925) ve demir-çelik sanayisi için Karabük (1939) kentleri örnek verilebilir (Yıldırım, 1991; Yassı, 2000; Öktem, 2004; Doğan, 2013: 211-233, Karatay, 2017).

$\mathrm{Bu}$ araştırmanın amacı; erken Cumhuriyet döneminde ulusal sanayi planları ve ekonomi politikalarına dayanan yer seçimi kararı kapsamında milli silah üretimine yönelik sanayi kenti olarak kurulan-gelişen Kırıkkale kentinin, mekânsal karakteristik ve işlevsel kimlik gelişim-değişim sürecinin kırılma noktaları bağlamında analitik haritalar eşliğinde değerlendirilmesidir. Bu değerlendirmeler; askeri-stratejik sanayi yatırım kararı temelinde mekânsal arka plan, tarihsel geçmiş, planlama deneyimleri ve sosyal analiz-kentleşme ve nüfus dinamikleri olmak üzere 4 (dört) başlık altında ele alınmıştır.

Araştırmada, yazılı araştırma kaynakları ve istatistiki veriler ile görsel materyallerin ayrıntıda yorumlanarak, üretilen analitik haritalar eşliğinde mekânsal ve işlevsel çözümlemelere yönelik değerlendirilmesine dayanan bir yöntem kurgulanmıştır.

$\mathrm{Bu}$ araştırmanın; sanayi kenti yer seçimi tercihlerinden farklı nitelik ve içerikteki stratejik yatırım kararı olarak silah sanayisinin yer seçimi kararlarının mekânsal ve işlevsel etkileri ve kendine özgü kentleşme deneyimi bakımından gelecekteki (olası) stratejik yatırım kararları alma-verme süreçlerine kentleşme dinamikleri ve yerleşme politikaları bağlamında katkı sunacağı düşünülmektedir.

\section{MEKÂNSAL ARKA PLAN: Konumsal Nitelik ve Kuruluş Gerekçesi}

Mekânsal arka plan başlı̆ğ altında Kırıkkale kenti, yerleşme deseni ve ulaşım olanakları ile kuruluş gerekçesi ve yer seçimi kararları olmak üzere ele alınarak değerlendirilmiştir.

\section{(a) Konumsal Nitelik ve Ulaşım Bağlantıları}

Kırıkkale kentinin coğrafi durumu irdelenirse, İç Anadolu Bölgesi'nin Orta Kızılırmak Bölümü'nde doğu-batı yönünden uzanan Kızılırmak Nehri kollarından Çoraközü Vadisi içinde yer aldığı görülmektedir. Yerleşme deseni açısından bakılırsa; kuzeyde Koçu Baba Dağı, güneyde Dinek Dağı olmak üzere ortalama 1.200-1.700 metre arasında değişen yükseltiler ile tanımlanan ortalama 750 metre rakımlı düzlük bölgeyi, Kırıkkale kentsel gelişme-yayılma alanı olarak ifade etmek mümkündür (Aydoğan, 1963: 169-185; Aydoğan, 1968: 219-250; Pehlivanl1, 1986: 25-26).

Bu çerçevede, Kırıkkale kentsel yerleşim alanının Çoraközü Vadisi'ne doğru alçalan eğimler arasında uzanan Çamlıca, Araba İnişi, Hacıbey, Deve Bağırtan ve Cin Deresi gibi mevsimlik akış rejimine sahip kuru derelerin oluşturduğu kuzey-güney yönlü vadiler zinciri üzerinde geliştiği söylenebilir (Şekil 1 ve Şekil 2).

Ulaşım olanakları açısından bakılırsa, Ankara Metropoliten Alanı'nın yaklaşık 76 km doğusunda bulunan Kırıkkale kenti,

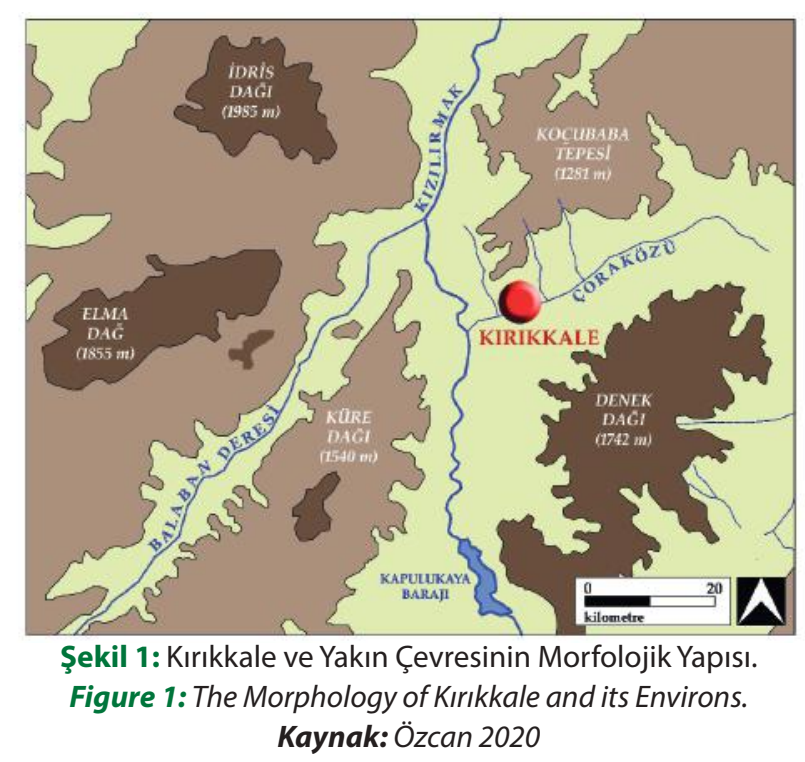




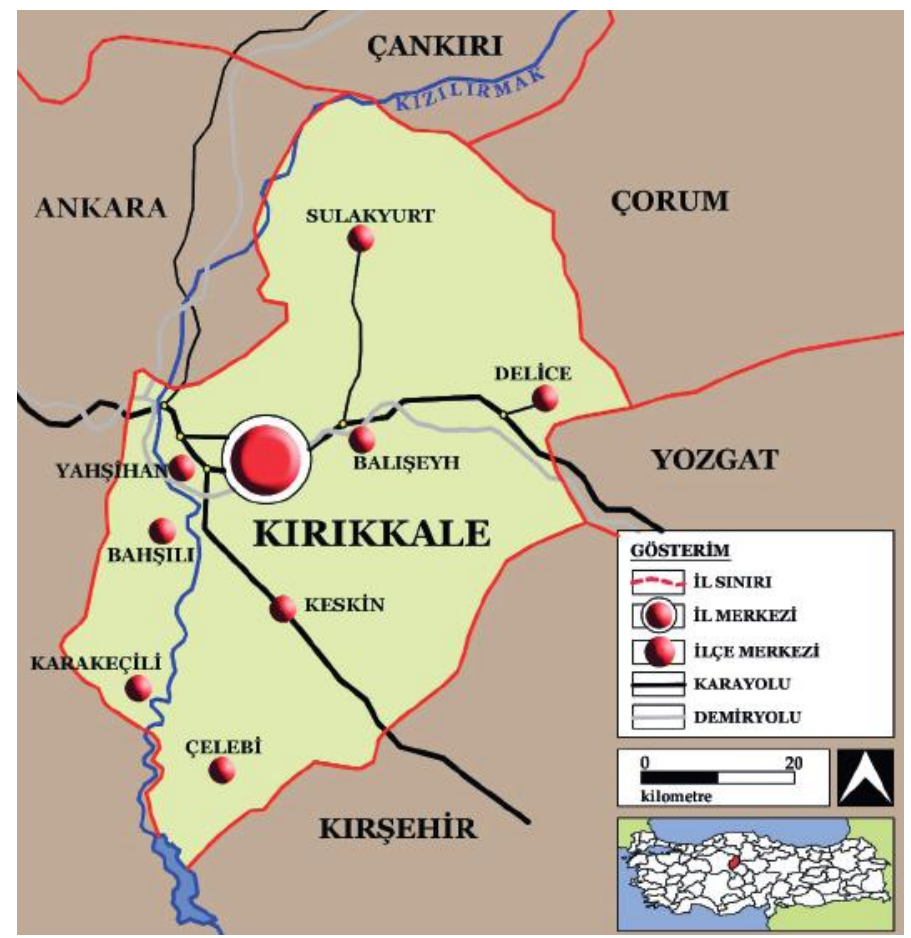

Şekil 2: Kırıkkale'nin Konumsal Durumu.

Figure 2: The Site Location of Kırıkkale.

Kaynak: Özcan 2020

Ankara-Erzurum Demiryolu güzergâhı üzerinde yer almakta olup Çorum üzerinden Doğu Karadeniz bağlantısını sağlayan Ankara-Samsun Devlet Karayolu (D-785), Kayseri üzerinden Doğu Anadolu bağlantısını sağlayan Ankara-Kayseri Devlet Karayolu (D-765) ve Ankara-Yozgat Devlet Karayolu'nun (D200) kesişim noktasında yer almaktadır. Bu nitelikleri ile malürün ve insan akımları bağlamında bölgeler-arası erişim sağlayan karayolu ve demiryolu bağlantıları açısından bölgelerarası kavşak noktası/geçiş merkezidir (Şekil 3).

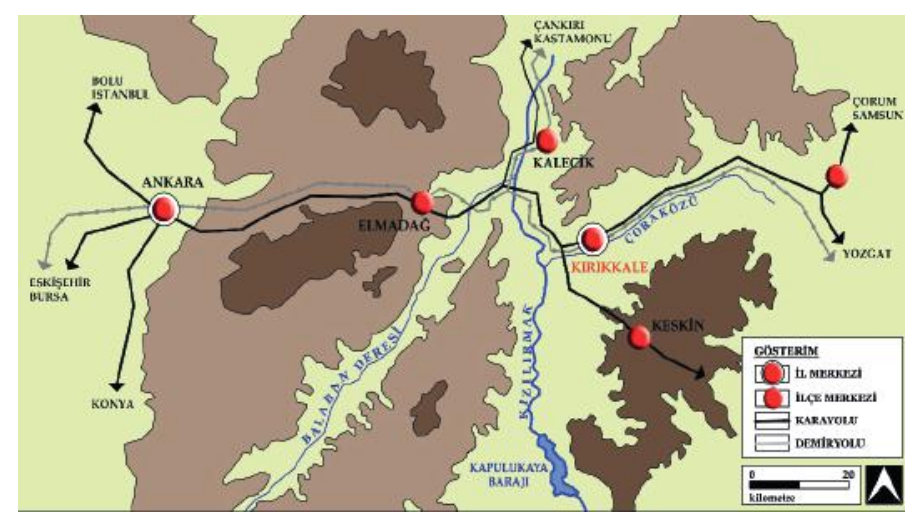

Şekil 3: Kırıkkale'nin Ulusal-Bölgesel Ulaşım Bağlantıları İçindeki Konumu.

Figure 3: Site Location of Kırıkkale in the National-Regional Transportation System.

Kaynak: Özcan 2020

\section{(b) Kuruluş Gerekçesi-Yer Seçimi Kararı}

Kırıkkale kentinin kuruluş gerekçesinin, İktisat Kongresi ve Cumhuriyetin ilk sanayi planları kapsamında öngörülen savunma sanayi yatırımlarına ilişkin yer seçimi kararları ile ilişkilendirmek mümkündür. Nitekim Birinci İzmir İktisat Kongresi'nde Kırıkkale'de savunma sanayisi kurulmasının gündem konusu edildiği kaydedilmektedir (Anonim, 1975: 116-117; Yücel, 2015: 26; Kızmaz, 207:54-55; Yurtoğlu, 2017: 81-112). Buradan hareketle, dönemin Askeri Fabrikalar Umum Müdürü Asım Paşa ve beraberindeki heyet tarafından Kayseri bölgesi ile KırıkkaleYahşihan bölgelerinde karşılaştırmalı incelemeler yapılarak, milli silah sanayisi yer seçimi için Kırıkkale bölgesinin belirlendiğini söylemek mümkündür (Evsile, 1992: 53-55; Sezgin, 2009: 71; Oğuz, 2006: 35-40).

$\mathrm{Bu}$ çerçevede, ulusal savunma sanayi yatırımı bağlamında Kırıkkale kentinin yer seçimi tercihi için 3 (üç) temel gerekçe olduğu düşünülebilir.

Birincisi, milli silah sanayinin dış tehditlerden uzak güvenli bir bölgede kurulmasına yönelik kaygılar esas olmak üzere Kırıkkale kentinin başkent Ankara'ya yakın erişilebilirliğinin yanısıra İç Anadolu Bölgesi'ni Doğu Karadeniz ve Doğu Anadolu bölgelerine bağlayan karayolu ve demiryolu bağlantıları üzerinde bulunmasına dayanan coğrafi-konumsal avantajlar olarak ifade edilebilir (Yılmazer, 2018: 62; Erdoğan, 1999: Gülyazı, 2004; Karadeniz, 2006; Vural, 2018). Bu noktada, özellikle Kırıkkale'nin yaklaşık 3 kilometre batısında Yahşihan İstasyonu varlığı, özellikle hammaddelerin taşınması-iletimi açısından önemli bir avantaj olarak görülmüştür (Kaynar, 2017: 179-200).

İkincisi ise özellikle Milli Mücadele döneminde Kırıkkale yakınındaki Keskin'de 1920 yılında kurulan Mühimmat (Fişek) İmalathanesi bağlamında silah yapımı-tamiri konularında uzmanlaşmış beşeri sermaye varlığı olarak görülebilir. Nitekim tarihsel kayıtlar, Milli Mücadele döneminde Keskin halkının silah üretim ve dağıtımında etkin rol üstlendiğine işaret etmektedir (Anonim, 1975: 115-116; Ersoy, 2017: 201-223).

Üçüncüsü, sanayi tesislerinin gereksinim duyabileceği su kaynakları ile kömür, demir ve kurşun gibi enerji ve hammadde kaynaklarına yakınlık olarak görülebilir (Anonim, 1975: 116117; Pehlivanl1, 1986: 23-24). Bu noktada, Türkiye Büyük Millet Meclisi arşiv kayıtlarında, Kızılırmak'ta Kırıkkale yakınlarında yapılan debi ölçümlerinde, kurulacak fabrikalar için yeterli enerji kaynağı sağlanacağına ilişkin tespitler, askeri 


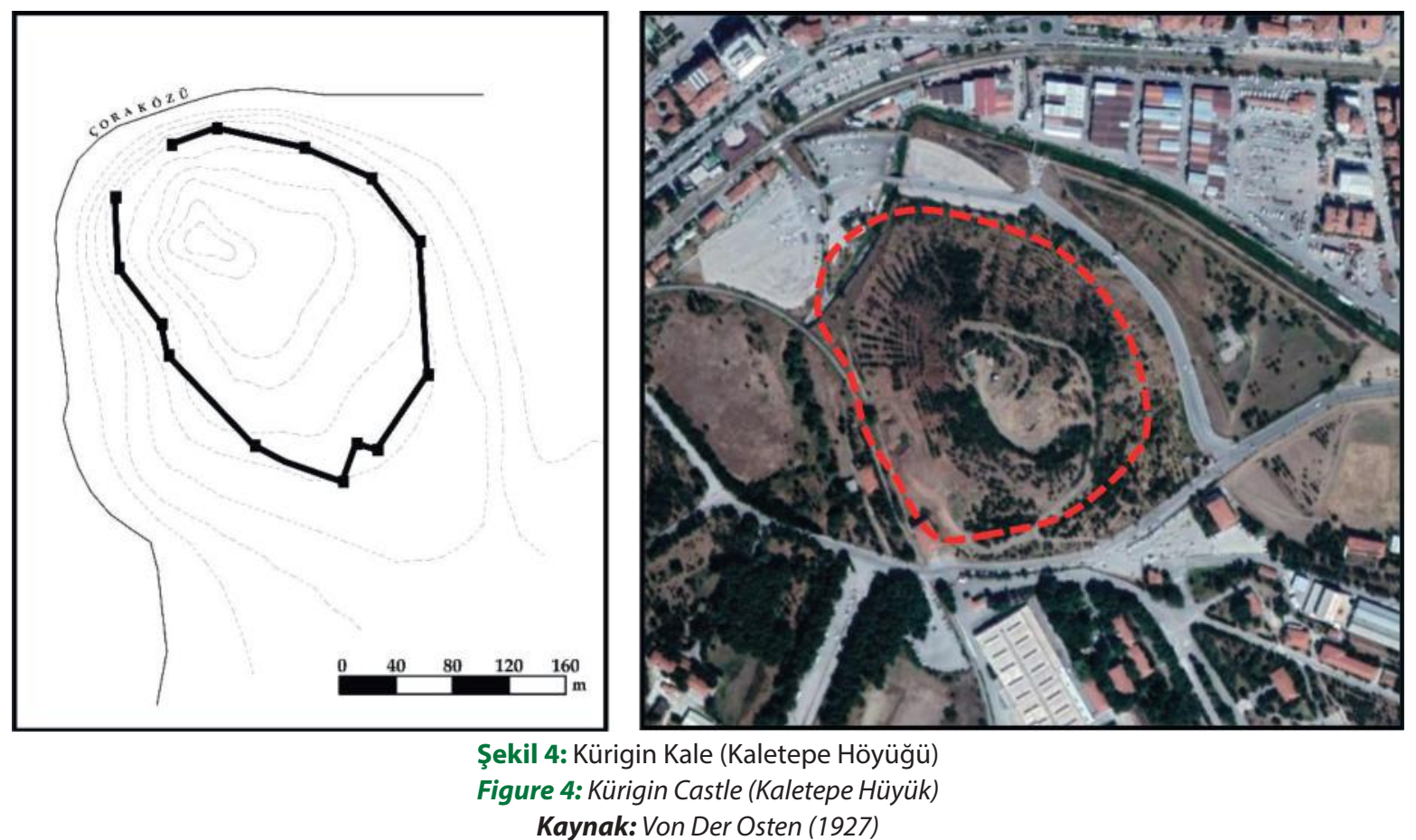

fabrikaların yer seçiminde enerji kaynağı olarak su kapasitesi varlığının etkili olduğunu düşündürmektedir. Nitekim sanayi tesisleri ve ek yapıları (Kırıkkale Garnizonu) Kızılırmak Nehri kolu olan Çoraközü Deresi boyunca yerleşmiştir (Kaynar, 2017:185-186).

Son olarak, bu gerekçelere yerel tarihi kaynaklarda Hüseyin Kâhya olarak kaydedilen Kırık Köyü muhtarının bir kısım arazileri silah fabrikalarının yapımı için Askeri Fabrikalar Müdürlüğü'ne bedelsiz bağışladığına ilişkin rivayet de eklenebilir (Yücel, 1959: 3; Yıldırım, 1966: 13-15; Aslıyüce, 1974: 71-73; Tekalp ve Diğerleri, 2017).

Dolayısıyla, ulusal silah sanayi yatırımları yer seçimi kararı için Kırıkkale kentinin seçilmesinde gerek bölgeler-arası coğrafi geçiş noktasına dayanan ulaşım-lojistik olanakları (demiryolu ve karayolu) gerekse yakın çevresinde silah sanayisine yönelik beşeri sermaye varlığı ile su kaynaklarına yakınlık yanısıra arsa temin kolaylıklarının temel gerekçeler olduğu ifade edilebilir.

\section{TARIHHSL GEÇMIŞ: Mekânsal Kuruluş ve Gelişim} Süreci

Kırıkkale kentinin tarihsel ve işlevsel kökenini; tarihsel kayıtlar ile toponomi/yer adı verilerine dayalı rivayetlere bağlı olarak Karakaya Tepesi eteklerinde kurulan Kırık Köyü ile Çoraközü Deresi yakınındaki Kaletepe Höyüğü olmak üzere 2 (iki) bağlamda değerlendirmek mümkündür.
Kaletepe Höyüğü açısından bakılırsa; 1926-1929 yıllarına tarihlenen yüzey araştırmaları önemli veriler sunmaktadır. $\mathrm{Bu}$ araştırmalarda, Kırıkkale yerleşim tarihinin Kürigin Kale adıyla bilinen Hitit kale yerleşimi ile ilişkilendirildiği görülür. Nitekim volkanik tepe niteliğindeki Kürigin Kale yüzeyinde yapılan kazılarda elde edilen çömlek ve heykel buluntuları, Hitit başkenti Hattuşaş (Boğazköy) ile Asur ticaret kolonisi Kaniş-Karum (Kültepe) ile ilişkili askeri ve stratejik bir merkez olduğunu düşündürmektedir (Von Der Osten, 1927: 288-294; Von Der Osten, 1927a: 60-65; Von Der Osten, 1930: 16; Tuncel, 1981: 334-335).

$\mathrm{Bu}$ bağlamda; Kürigin Kale yerleşimi, başkent Hattuşaş çevresinde Hitit savunma sistemi kapsamında oluşturulan kaleler ağının lojistik bileşenlerinden birisi olarak değerlendirilebilir (Przeworski 1929: 25). Diğer taraftan, Kürigin Kale yerleşimini çevreleyen sur-duvar kalıntılarında yapılan incelemeler, Çoraközü Vadisi'ne hâkim konumsal niteliği ile Yunan-Roma ve Bizans dönemlerinde askeri-stratejik işleve sahip kale yerleşmesi olarak iskân sürekliliğinin varlığına işaret sayılmalıdır (Şekil 4 ve Resim 1).

Kaletepe Höyüğü eteklerinde 1935-1940 döneminde gerçekleştirilen teknik altyapı-yol yapımı içerikli imar faaliyetlerinde Hitit çağına tarihlendirilen buluntular, Orta Kızılırmak Havzası'nda bölgeler-arası geçiş noktası niteliğindeki konumu ile yerleşim-iskân sürecinin eski çağlara dek uzandığını ortaya koyması bakımından önemlidir (Ay, 1995: 31-38; Örkçüoğlu, 1990: 42). Nitekim Orta Kızılırmak Havzası'na 

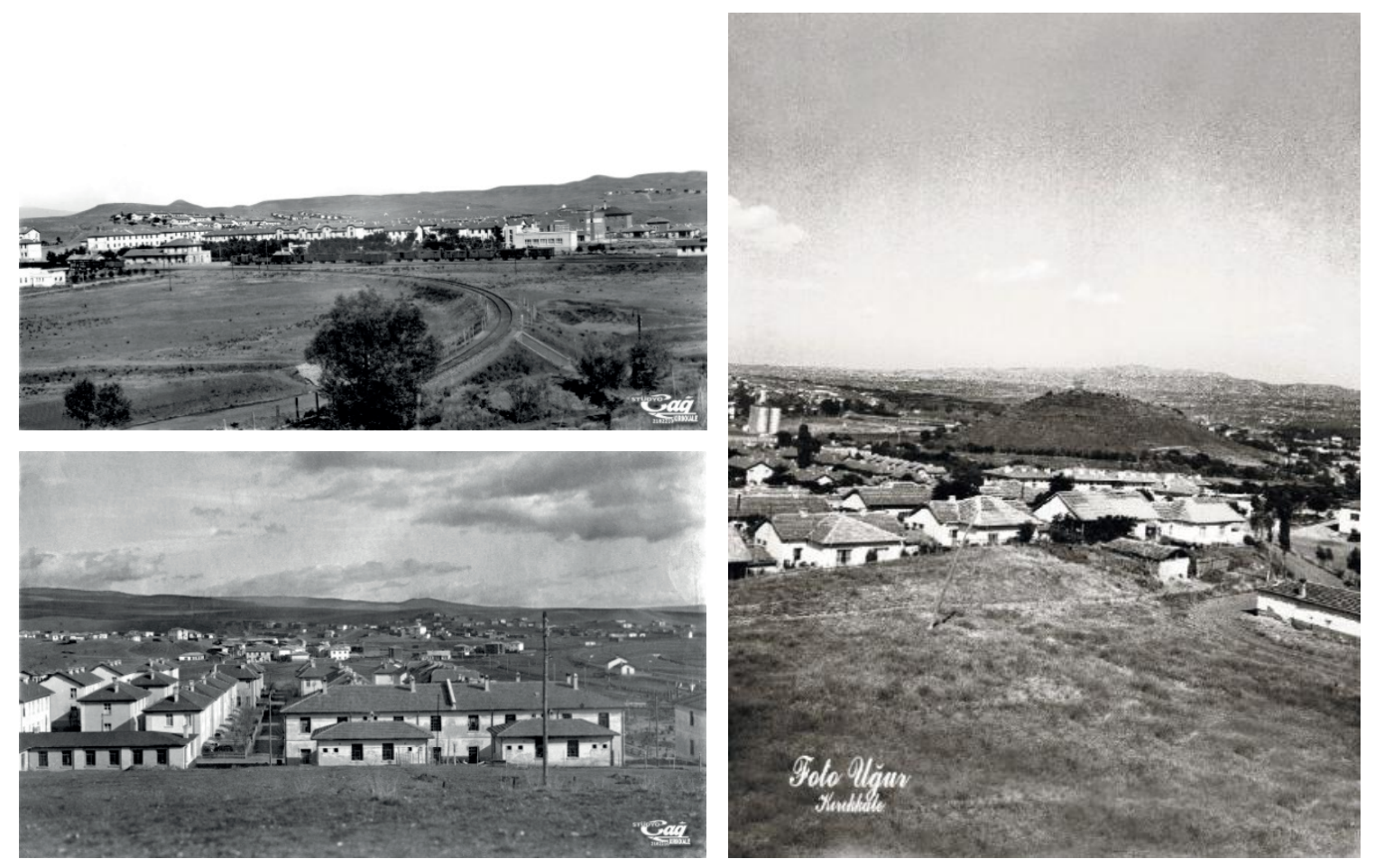

Resim 1: Kırıkkale Fabrikalar Mahallesi (Pavyonlar) ve Kaletepe.

Picture 1: Views of Kırıkkale Factories Quarter (called Pavyon) and Kaletepe. Kaynak: Kırıkkale Belediyesi Arşivi (Stüdyo Çağ ve Foto Uğur)

yönelik arkeolojik araştırmalar, Kırıkkale ve çevresi yerleşim tarihinin tarih öncesi dönemlere/paleolitik çağlara dek uzandığını ortaya koymaktadır (Çiçek, 2018).

Türk-İslam yerleşim süreci açısından bakılırsa, Kırıkkale ve yakın çevresindeki Balışeyh, Koçu Baba, Hasan Dede, Şeyh Şami, Hıdırşey, Aydınşeyh gibi yerleşim isimlerinin varlığı, Türk-İslam yerleşim sürecinde Türkmen gruplarının dini kimlikli şahsiyetler çevresinde örgütlenmesine dayalı bir yerleşim sürecinin gerçekleştiğini düşündürmektedir (Önder, 1972: 223-224; Kankal, 2013: 3-31; Özgür, 2019: 17-22). Nitekim onyedinci yüzyıla tarihlenen seyahat anlatılarında, Kırıkkale yakın çevresinde Koçu Baba ve Şeyh Şami gibi köylerin varlığına ilişkin kayıtlar, yerleşim sürecinin kültürel arka planını ortaya koyması bakımından önemlidir (Evliya Çelebi, 2006: 503-504).

Tarihsel kayıtlar incelenirse, Kırık Köyü'nün 16.-17. yüzyıllarda Seyhan-Ceyhan ve Göksun Havzası'ndan Kızılırmak Havzası'na yönelen konar-göçer Türkmen gruplarından, Kırıklı ya da Kırıklu cemaatinin yerleşmesi ile kurulduğu anlaşılmaktadır. Nitekim şer'iye sicilleri ve mühimme defterleri gibi özgün tarihi kaynaklar irdelenirse, Kırık ya da Kırıklu veya Kırıkkal yer adının varlığını tespit edebilmek mümkündür (Metin, 1997; Metin, 2007; Pekgöz, 2002; Güner ve Ertürk 2004: 54).
Buna göre; Kırık Köyü'nün varlığına ilişkin en erken kayıt, 16. yüzyılda kıtlık ya da kıran geçirdiğine ilişkindir (Kankal, 1998: 225-239). Sonraki kayıt ise Kırıklu Köyü halkına 17. yüzyıl başında eşkıya saldırılarından korunmak için civardaki kalenin tamir edilmesi ve kullanımı için izin verildiğine ilişkindir (Tuncel, 2002: 446-447). Bu kayıtlar, Kırık Köyü yerleşim sürecinin 16. yüzyıldan itibaren başladığını göstermesinin yanısıra yakınlarında bir kale yerleşmesinin -olasıllkla Kürigin Kale - varlığına da işaret etmesi bakımından önemlidir.

Kırıkkale'nin tarihsel kuruluş sürecini ise yer seçimi kararlarını takiben mühimmat (1929), döküm-haddehane (1929), pirinç (1929), çelik (1933), tüfek (1934), top (1937), barut (1938) olmak üzere askeri fabrikalar ve destek tesislerin (sosyal tesis-lojman vb.) kurulması ilişkilendirmek mümkündür (Anonim, 1940: 123). $\mathrm{Bu}$ çerçevede, Kırıkkale kentinin mekânsal kuruluşu, askeri fabrikaların kurulması ile eş zamanlı olarak değerlendirilmelidir.

Kırıkkale kentinin tarihsel bağlamda mekânsal kuruluşgelişim aşamalarını, sosyo-ekonomik gelişmeler ve mekânsalidari gereklilikler bağlamında kırılma noktaları açısından 6 (altı) aşamalı bir süreçte ele almak mümkündür.

İlk aşama; Çoraközü Deresi güneyinde silah fabrikaları (Fabrikalar Mahallesi) ile işçi-memur lojmanlarının (Pavyonlar 
Mahallesi) kurulmasıdır (Anonim, 1940: 1923). Dolayısıyla, 1925-1935 dönemini kapsayan süreçte, Kırıkkale kentinin sanayi alanı ve konut alanı olmak üzere ikili bir mekânsalişlevsel desen gösterdiği söylenebilir. Bu çerçevede, planlı konut yerleşkesi niteliğindeki "Kırıkkale Garnizonu” veya "Pavyonlar Mahallesi" olarak anılan bölgeyi, Kırıkkale kentinin tarihsel omurgası ve ilk kuruluş yeri olarak tanımlamak mümkündür (Resim 1 ve Şekil 5).

İkinci aşama ise; 1935-1945 döneminde yeni fabrikalar kurulmasına koşut artan işgücü gereksinimine dayalı olarak yakın çevre kentler ve kırsal alanlardan yerleşimcilerin iskânı edilmesi sürecidir. Bu süreçte, bir taraftan barut evleri ve pirinç evleri gibi planlı işçi ve memur lojmanlarının inşa edildiğ $i^{1}$, diğer taraftan ise derme-çatma konutlar ve yetersiz teknik altyapısı ile yerel halk arasında "Toprak Mahalle" olarak adlandırılan plansız-denetimsiz yerleşim alanının geliştiği görülmektedir. Devamında, nüfusun temel ihtiyaçların karşılanmasına yönelik sosyal-kültürel donanımlar ile ekonomik-ticari merkez işlevindeki çarşı bölgesinin kurulduğu anlaşılmaktadır (Hancı, 1945: 20). Dolayısıyla, Kırıkkale kentinin mekânsal bağlamda düzenli-plan konut bölgesi ile kerpiç veya toprak malzemeden yapılmış plansız konut/ gecekondu alanları olmak üzere ikili bir mekânsal örüntüye sahip olduğunu söylemek mümkündür (Şekil 5).
Bu çerçevede, 1935-1945 döneminin mekânsal öncelikleri sosyal-kültürel ve ekonomik altyapı donanımları ile teknik altyapı gereksinimleri olmak üzere 3 (üç) başlıkta toplanabilir.

Birincisi, sanayi tesisleri ile kent nüfusunun gereksinimi için su ve elektrik gibi enerji ihtiyacının karşılanması ile yaşamsağlık koşullarının iyileştirilmesi içerikli teknik altyapı faaliyetleridir. Nitekim arşiv belgeleri irdelenirse ${ }^{2}$, özellikle sanayi tesisleri ve kentin su ve elektrik ihtiyacının karşılanmasına yönelik altyapı tesislerinin yapılması ile halk sağlı̆̆ için Çoraközü Deresi çevresindeki bataklık alanlarının kurutulması/ ıslahına yönelik önlemler alınmasının temel öncelikler arasında olduğu söylenebilir.

İkincisi, ekonomik-ticari altyapı gereksinimlerine ilişkin altyapının oluşturulmasıdır. Nitekim Kırıkkale üzerine hazırlanan bir monografi çalışmasına göre, 1945 yılında kentte yaklaşık 480 (dört yüz seksen) adet dükkân-mağaza, 13 (on üç) adet han-otel, 7 (yedi) adet firın olduğuna ilişkin kayıtlardan, küçük ölçekli bir kentsel merkez oluşumunun başladığını söylemek mümkündür (Hanc1, 1945: 17).

Üçüncüsü ise, kent nüfusunun temel ihtiyaçlarının karşılanmasına yönelik sosyal-kültürel altyapı donanımlarının karşılanmasıdır. Bu açıdan bakılırsa, Kırıkkale Ortaokulu (1938)

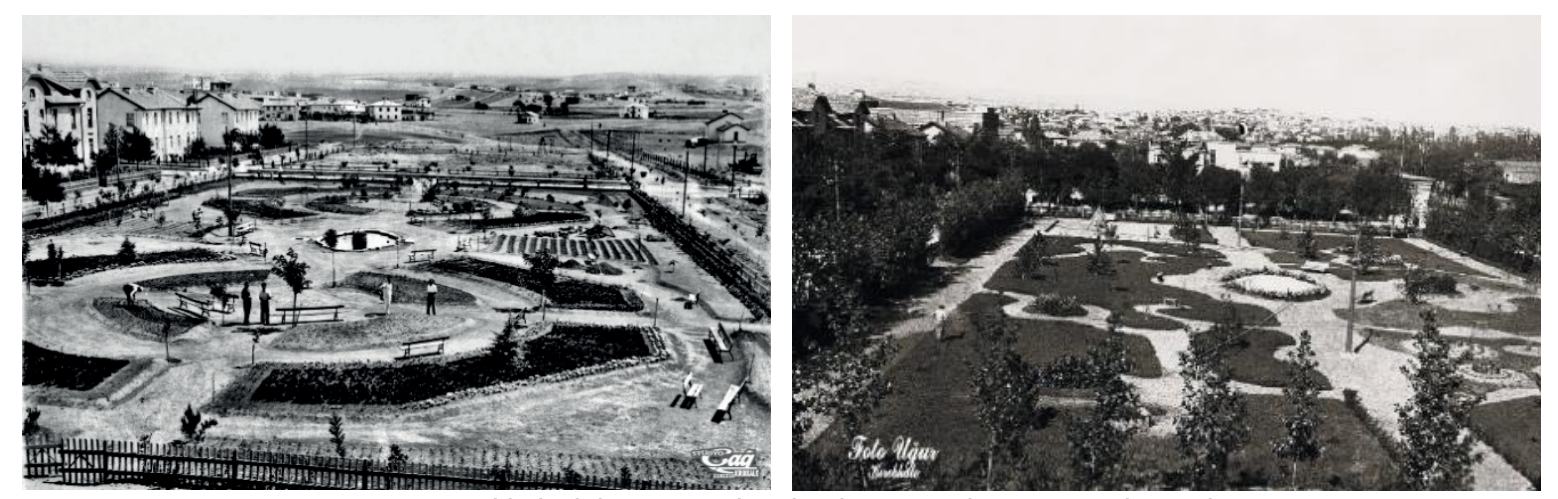

Resim 2: Kırıkkale'deki Simgesel Mekânlar: Atatürk Anıtı ve Şehir Parkı.

Picture 2: The Symbolic Spaces in Kırıkkale: Atatürk Monument and City Park Kaynak: Kırıkkale Belediyesi Arşivi (Stüdyo Çağ ve Foto Uğur)

1 Arşiv belgesi (1932, 23.05). [Kırıkkale'de inşa ettirilen iş̧̧i evlerinin noksanlarını tamamlamak için gelecek seneye sarkan sözleşme yapılması] Cumhurbaşkanlığı Devlet Arşivleri (Belge No:30-18-1-2/29-41-18), Ankara.

2 Arşiv belgesi (1930, 03.09). [Kırıkkale'deki askeri fabrikalarla şehrin su ihtiyacını karşılayacak tesislerin ihalesi]. Cumhurbaşkanlığı Devlet Arşivleri (Belge No: 30-18-1-2/13-60-4), Ankara. Arşiv belgesi (1930, 10.08). [Kırıkkale'nin su ihtiyacının temini için yapılacak kuyuların pazarlık usulüyle yaptırılması]. Cumhurbaşkanlığı Devlet Arşivleri (Belge No: 30-18-1-2/13-54-20). Arşiv belgesi (1935, 14.05). [Kırıkkale'de elektrik kuvvet merkezi ile buna ait su tesisatı yaptırılmas1]. Cumhurbaşkanlığı Devlet Arşivleri (Belge No: 30-18-1-2/54-37-20). Arşiv belgesi (1935, 17.07). [Ankara ve Kırıkkale'nin elektrik ihtiyacını temin için Kızılırmak üzerinde elektrik üretimi sağlayacak bir tesis kurulması]. Cumhurbaşkanlığı Devlet Arşivleri (Belge No: 30-10-0-0/157-103-3). Arşiv belgesi (1942, 28.02). [Kırıkkale silah fabrikaları çevresindeki bataklıkların durumu ve sıtma ile ilgili rapor]. Cumhurbaşkanlığı Devlet Arşivleri (Belge No: 30-10-0-0/177-22313). Arşiv belgesi $(1941,10.12)$. [Kırıkkale askeri fabrikalarında çalışan işçilerin, sıtmadan korunmaları için çevredeki bataklıkların kurutulması ve diğer önlemler]. Cumhurbaşkanlığı Devlet Arşivleri (Belge No: 30-10-0-0/177-223-11). Arşiv belgesi (1942, 28.08). [Kırıkkale ve Küçük Yozgat askeri fabrikalarında üretimi arttırmak için su getirilmesi ve lojman yapılmasına öncelik verilmesi]. Cumhurbaşkanlığı Devlet Arşivleri (Belge No: 30-10-0-0/58-395-12. 
ile Askeri Sanat Lisesi (1938) ile Tinaz İlkokulu (1944) gibi eğitim kurumlarının inşa faaliyetleri ile Halkevi (1942) kurulması önemlidir (Pehlivanll, 2008: 127-147; Balkan, 2014: 61-66; Kıraç, 2018: 31-35). Diğer taraftan, beş yüz kişilik sinema salonu inşası ile Atatürk Anıtı inşasına ilişkin kayıtlar ${ }^{3}$, kültür ve siyasa/ideoloji odaklı kent kimliği oluşturulması ve Cumhuriyet rejiminin simgeleştirilmesine yönelik mekânsal düzenlemeler ${ }^{4}$ olarak değerlendirilebilir (Resim 2).

İlk kuruluş sürecini takiben, istihdam olanaklarına dayalı gerek mekânsal-işlevsel kullanımlar gerekse demografik ve ekonomik gelişmeler bağlamında sanayi odaklı cazibe merkezi niteliği kazanan Kırıkkale, kent yönetimi ve hizmet sunumu bağlamında ortaya çıkan gereksinimlere koşut olarak gerçekleştirilen idari düzenlemeler eşliğinde 1929 yılında bucak, 1939 yılında belediye, 1944 yılında ise ilçe statüsü kazanmıştır (Esirci, 1991: 46).

Üçüncü aşama; 1945-1955 döneminde özellikle Yozgat, Çorum, Kırşehir gibi bölge kentleri ile yakın çevre kırsal alanlardan sanayi istihdam olanakları bağlamında hızlı göç ve denetimsiz kentleşme sürecine konu edilmesi olarak görülmektedir (Kunter, 1961: 9-12). Bu sürecin mekânsal yansımasının ise Kırıkkale kentinin kuzey-güney yönünde uzanan kuru dere yatakları niteliğinde vadiler boyunca tamamen denetimsiz ve plansız biçimde gelişen konut alanları biçiminde olduğu anlaşılmaktadır (Resim 3 ve Şekil 5).

Nitekim döneme ilişkin arşiv belgelerinde; Kırıkkale halkının merkezi yönetimden temel taleplerinin yol yapımı, telefon hattı kurulması, içme ve kullanma suyu temini gibi teknik altyapı gereksinimlerinin karşılanması üzerine olması, Kırıkkale kentinin plansı-denetimsiz kentleşme sürecinin göstergesi olarak görülebilir (Kıraç, 2018: 72-75).

Arşiv belgeleri irdelenirse ${ }^{5}$, Kırıkkale'de yerleştirilen kamu personelinin (memur-işçi) konut gereksinimlerinin karşılanmasına yönelik olarak -özellikle işçi ve ögretmenler için- konut yapı kooperatiflerinin teşvik edildiği görülür. $\mathrm{Bu}$ teşvikler, plansız-denetimsiz inşaat faaliyetlerinin önlenmesi ve sağlıklı konut üretimi-sunumu açısından ilk örgütlü çabalar olarak değerlendirilmelidir. Diğer taraftan, Kırıkkale'de ilk finans kurumlarının-bankacılık faaliyetleri ile esnaf desteklerinin başladığına ilişkin arşiv belgeleri ${ }^{6}$, kentsel sermaye birikim sürecinin oluşmasi/gelişmesi ve küçük-orta ölçekli esnafların desteklenmesi bağlamında kentsel ekonomik yaşamın gelişmesi bakımından önemli görülmelidir.

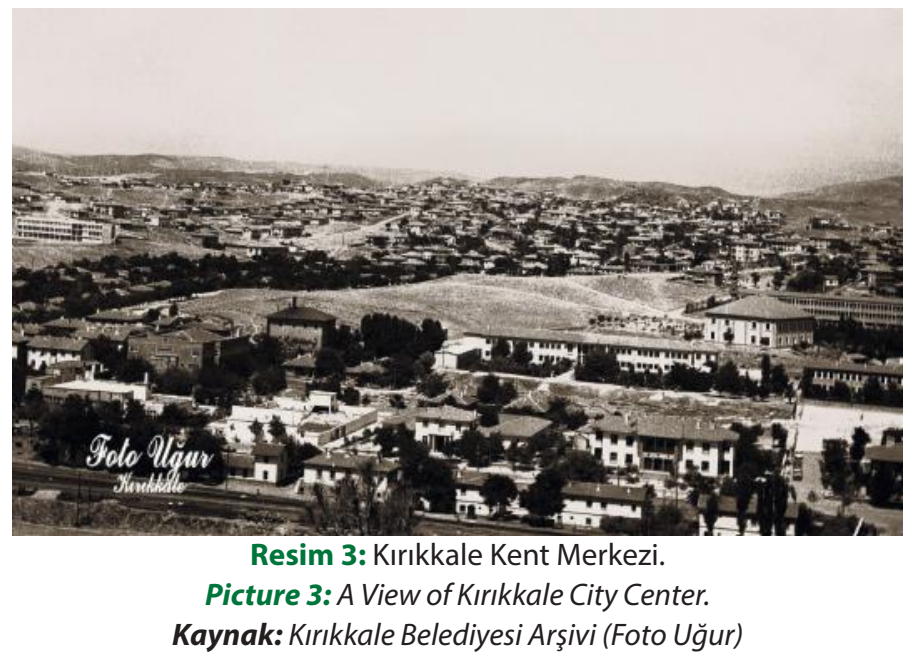

Dördüncü aşama; 1955-1970 zaman aralığını kapsayan bu dönemde Kırıkkale hakkında hazırlanan rapora ilişkin arşiv belgesinde ${ }^{7}$; Kırıkkale'nin 1967 yılı itibarıyla 70.000'i aşan nüfusu, mevcut eğitim ve kültür altyapısı, sağlık kurumları, sanayi (fabrika, atölye, vb.) ve ticarete (bankacılık/finans ve kefalet kooperatifi vb.) dayalı ekonomik kapasitesi ile "il olma" potansiyeli kazandığı kaydedilmektedir. Nitekim 1960 yılında yaklaşık 42.000 olan nüfusun, on yıl içinde iki kat artış ile 1970 yılında yaklaşık 90.000 nüfusa ulaşması, Kırıkkale'nin “il olma" potansiyelini destekler niteliktedir. $\mathrm{Bu}$ nüfus dinamiğinin mekânsal yansıması ise kentin güneydoğusunda Karşıyaka, güneybatısında Kızılırmak olmak üzere yeni mahallelerinin kurulması biçiminde olmuştur (Şekil 5).

3 Arşiv belgesi (1938, 01.07). [Kırıkkale garnizonuna dikilecek Atatürk heykelinin Nurat Suman'a pazarlıkla yaptırılması]. Cumhurbaşkanlığı Devlet Arşivleri (Belge No: $30-18-1-2 / 83-60-4)$.

4 Cumhuriyet dönemi kentlerindeki simgesel mekânlar için bakınız: Tekeli ve Ortaylı, 1987: 89-91.

5 Arşiv belgesi $(1954,15.03)$. [Kırıkkale Fabrikaları İşçileri Yapı Kooperatifi’nin kurulmasına izin verilmesi]. Cumhurbaşkanlığı Devlet Arşivleri (Belge No: 30-18-12/135-28-8). Arșiv belgesi $(1954,10.04)$. [Kırıkkale Öğretmenleri Yapı Kooperatifi'nin kurulmasına izin verilmesi]. Cumhurbaşkanlığı Devlet Arșivleri (Belge No: 30-18-1-2/135-37-12). Arşiv Belgesi (1954, 15.03). [Kırıkkale MKE Kurumu İşçileri Yapı Kooperatifi'nin kurulmasına izin verilmesi]. Cumhurbaşkanlığı Devlet Arşivleri (Belge No: 30-18-1-2/135-37-16).

6 Arşiv belgesi $(1954,19.01)$. [Demirbank Türk Anonim Şirketi tarafindan Karabük ve Kırıkkale'de birer şube açılmasına izin verilmesi]. Cumhurbaşkanlığı Devlet Arşivleri (Belge No: 30-18-1-2/138-109-20). Arşiv belgesi (1954, 11.02). [Kırıkkale Esnafı Kefalet Kooperatifi'nin kurulmasına izin verilmesi]. Cumhurbaşkanlığı Devlet Arșivleri (Belge No: 30-18-1-2/138-121-2). Arșiv belgesi (1952, 29.05). [Akbank Türk Anonim Ortaklığı'nca Denizli, Polatlı ve Kırıkkale ile İzmir'in Başdurak, Karşıyaka, Tepecik ve Yenigün semtlerinde birer şube açılmasına izin verilmesi]. Cumhurbaşkanlığı Devlet Arşivleri (Belge No: 30-18-1-2/129-45-20).

7 Arşiv belgesi (1967, 07.10). [Kırıkkale'nin istekleri]. Cumhurbaşkanlığı Devlet Arşivleri (Belge No: 30-1-0-0/120-763-4). 

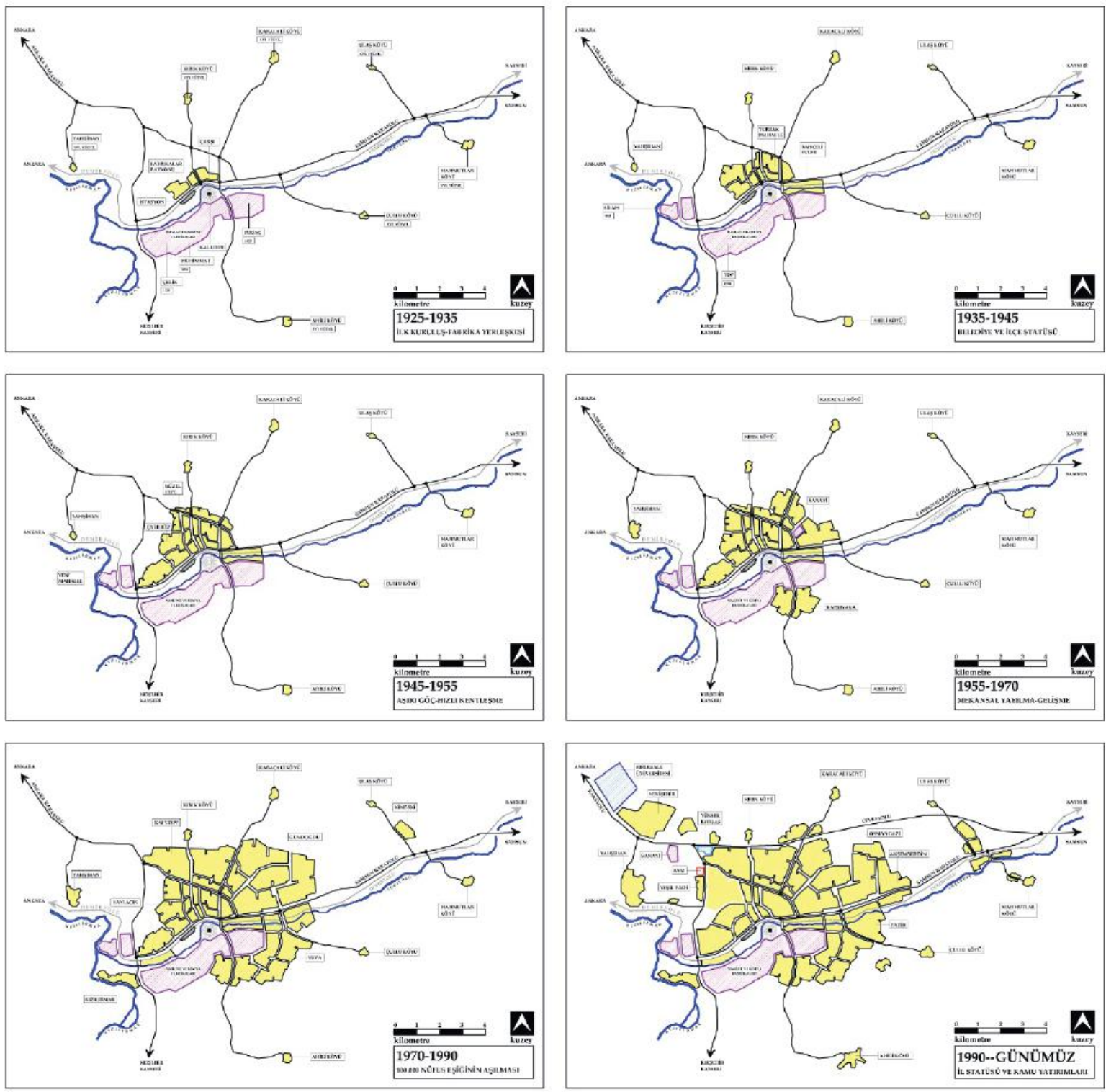

Şekil 5: Kırıkkale'de Kentsel Gelişmenin Aşamaları.

Figure 5: The Stages of Urban Development in Kırıkkale City.

Kaynak: Yazılı ve görsel veriler esas alınarak kurgulanmıştır (Özcan 2020).

Beşinci aşama: Kırıkkale nüfusunun orta ölçekli kentler için nüfus eşiği olarak ifade edilen 100.000 nüfus kriterini aştığ1 1970-1990 dönemidir. Bu süreç, Kırıkkale'de -askeri fabrika lojmanları sonrası- ilk toplu konut deneyimlerinin gerçekleştirilmesi bakımından önemli görülmelidir. Nitekim Kırıkkale kentinin kuzey yamaçlarında gecekondu önleme bölgesi olarak belirlenen alanda toplu konut projesi yoluyla oluşturulan Kaletepe Toplu Konut Bölgesi, kuzey yönündeki kentsel gelişme eğilimleri açısından önemli bir dinamik olmuştur. Bu süreçte, kuzeyde kırsal yerleşme niteliğindeki Kırık Köyü’nün kente eklemlendiği anlaşılmaktadır (Şekil 5).
Altıncı aşama ise 1990 ve sonrası dönem olarak söylenebilir. $\mathrm{Bu}$ dönemdeki en önemli gelişme; hızlı nüfus artışına ve kentleşme sürecine koşut olarak 1989 yılında İl statüsü kazanmasıdır (Esirci, 1991: 53-65). Kentsel gelişme süreci açısından önemli gelişmeler ise; Orta Anadolu Petrol Rafinerisi'nin faaliyete başlaması (1987), Kırıkkale Üniversitesi’nin hizmete açılması (1992), Organize Sanayi Bölgesi'nin kurulması (1995) ve kentin doğusunda plansız ve kaçak gelişmelerin önlenmesine yönelik olarak imar planı kararları eşliğinde Osmangazi ve Akşemseddin mahallelerini kapsayan konut gelişme alanlarının yerleşime açılması olarak sayılabilir (Gülyazı, 2004: 52-54; Karadeniz, 2006: 100-104). 
Bu süreçte, Kırıkkale Üniversitesi'nin hizmete açılması, Kırıkkale'nin gerek batı yönündeki mekânsal gelişme eğilimlerinin hızlanması gerekse kentsel sosyal-ekonomik yaşama katkısı açısından önemli görülmelidir (Işık, 2008: 159-181).

2000 sonrası dönemde ise kentin batısında Kırıkkale Üniversitesi Hastanesi ile Bölge Hastanesi’nin açılması, kuzeyde Ankara-Samsun Çevre Yolu'nun hizmete alınması ve kent merkezi ile Kırıkkale Üniversitesi Yerleşkesi ve Organize Sanayi Bölgesi arasında planlanan Kaleray Projesi ${ }^{8}$ gibi ulusal-bölgesel içerikli kamu hizmet yatırımları, kentsel gelişme dinamiklerini etkileyen önemli sosyal ve teknik altyapı yatırımları olarak sayılabilir. Bu gelişmeler sonucunda, kentsel gelişme sürecinin batıda Kırıkkale Üniversitesi Yerleşkesi ve Yahşihan İlçesi yönünde mekânsal bütünleşme eğilimlerinin artarak, devam etmesi beklenmelidir (Şekil 5).

\section{PLANLAMA DENEYIMLERİ: Belediye Kurulması ve Ímar Planları}

Kırıkkale kentine yönelik ilk mekânsal planlama deneyimi, askeri sanayi tesisleri ve eklentilerinin kurulmasından yaklaşık yirmi yıl sonrasına tarihlenmektedir. Esas itibarıyla, planlama çalışmalarının 1939 yılında belediye teşkilatının kurulması ile gündeme geldiğini söylemek mümkündür (Hanc1, 1945: 1718). Nitekim 1948 yılında kentin ilk haritalama çalışması, devamında ise imar planı yapım çalışmalarının başlatıldığı anlaşılmaktadır (Taner ve Taner, 1948: 72-75; Anonim, 1948: 19-22).

Şüphesiz, sanayi yatırımlarına dayalı hızlı kentleşme ve nüfus artışına koşut plansız-denetimsiz mekânsal gelişme sürecinin, imar planı yapım çalışmalarının gündeme alınmasında etkili olduğu açıktır. Nitekim kentteki plansız gelişme sürecinin mekânsal ürünü olarak ilk gecekondu alanlarının 1930 yıllarından itibaren başladığ1 kaydedilmektedir (Örkçüoğlu, 1990: 40).

$\mathrm{Bu}$ çerçevede, kentsel gelişme sürecinin denetim atına alınmasına yönelik ilk planlama deneyimi, 1948 tarihli imar planıdır. İmar planı kapsamında Kırıkkale kenti 63 hektar yerleşik alan ve 133 hektar gelişme alanı olmak üzere toplam 196 hektar kentsel yerleşim alanı olarak tasarlanmıştır (Taner ve Taner, 1948: 72-75; Anonim, 1948: 19-22).
Plan Açıklama Raporu incelenirse; kentsel gelişmenin, Fabrikalar Mahallesi ve çevresini kapsayan yerleşik alanlar ile gelişme alanları olmak üzere 2 (iki) bölümde ele alındığı görülür Bu çerçevede, kentsel meydan ve yeşil alan oluşumlarına öncelik verilmiş, resmi kurum alanları, eğitim alanları, sanayi ve ticaret alanları (han-pazar alanları) ile meydan-park gibi açık alanlar tasarımı olmak üzere yeşil alan kullanımları etkin arazi kullanım kararları ile 3 (üç) kademeden oluşan bir ulaşım sistemi kurgulanmıştır (Şekil 6 ve Şekil 7).

Ancak, Plan Açıklama Raporu içeriğinde dikkat çekici konu, Kırıkkale'nin nüfus artış hızının Türkiye ortalamasının oldukça üzerinde olması ve nüfus gelişme eğilimlerinin belirsizliği gerekçeleri esas olmak üzere geleceğe yönelik nüfus tahminlerinin yapılmamış olmasıdır (Anonim, 1948: 72). Bu durum, dönemin sanayileşme koşut hızlı kentleşme dinamiklerine dayalı denetimsiz nüfus artışı ve yapılaşma eğilimlerinin kentsel gelişme süreci üzerindeki öngörülemeyen etkisini ortaya koymaktadır. Nitekim 1960 yılına tarihlenen arşiv belgelerinde ${ }^{9}$ Kırıkkale'deki konut alanlarının yaklaşık \%76 bölümünün gecekondu ve kaçak yapı olduğuna ilişkin tespitler, 1948 tarihli imar planının yetersiz kaldığını, hızlı nüfus dinamiklerine koşut plansız kentleşme sürecinin denetim altına alınmadığı göstermektedir.

Bu noktada, "kentsel gelişmenin imar planı sınırlarını aştığı, yeni imar planı yapımı için Iller Bankası ile temasa geçildiği”, devamla, "imar planı yapılmasının sayılmayacak menfaatleri olacağına" ilişkin kayıtlar ${ }^{10}$, Kırıkkale Belediyesi ve yerel siyaset temsilcilerinin, kentleşme sürecinin denetim altında alınması konusunda imar planı yapılması gerekliliğinin bilincinde/farkında olduğunu göstermesi bakımından önemlidir.

Kırıkkale kentine yönelik ikinci planlama deneyimi ise; kentsel nüfus artış eğilimlerinin 1970'de 90.000, 1975'te de 100.000'i aşarak yaklaşık 140.000 nüfusa ulaştığı döneme tarihlenmektedir. $\mathrm{Bu}$ durum, planlama deneyimlerinin öncelikli hedefinin sanayi istihdam olanaklarına dayalı göç ile gelen nüfusunun kentsel yerleşim alanında dengeli ve düzenli biçimde dağıtılması ile sosyal ve teknik altyapı gereksinimlerinin karşılanması olduğunu düşündürmektedir.

Bu süreçte, 1968, 1972 ve 1976 yıllarında olmak üzere kentsel gelişmenin denetim altına alınmasına yönelik 3 (üç) imar

8 Kırıkkale Kaleray Projesi değerlendirmesi için bakınız: Doğan ve Kablan, 2016: 431-437, Arıkan ve Diğerleri, 218:6-11.

9 Arşiv belgesi (1967, 07.10). [Kırıkkale'nin istekleri]. Cumhurbaşkanlığı Devlet Arşivleri (Belge No: 30-1-0-0/120-763-4).

10 Arşiv belgesi (1967, 07.10). [Kırıkkale'nin istekleri]. Cumhurbaşkanlığı Devlet Arşivleri (Belge No: 30-1-0-0/120-763-4). 


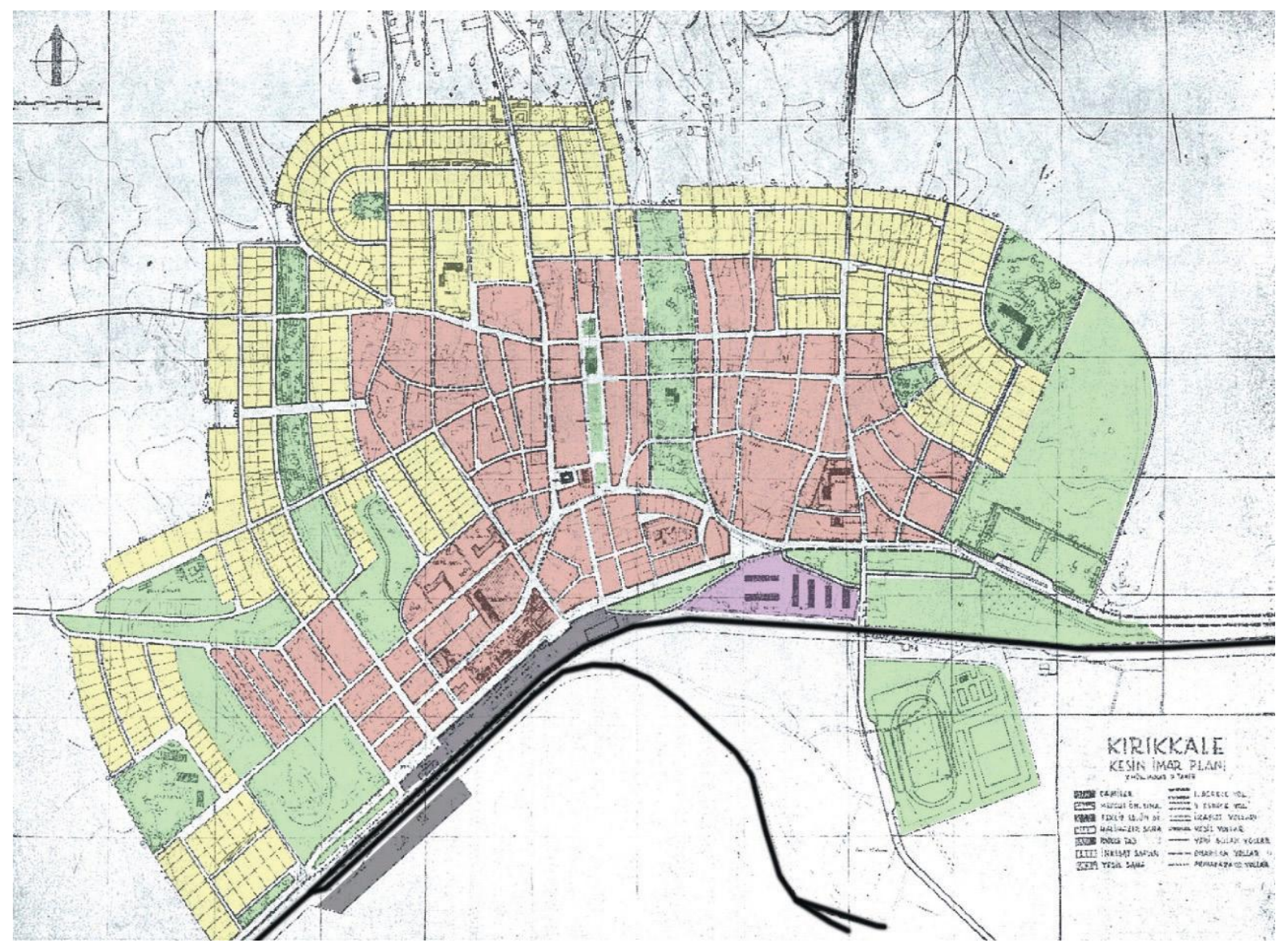

Şekil 6: Kırıkkale kenti ilk imar planı (1948).

Figure 6: The First Development Plan for Kırıkkale City (dated 1948).

Kaynak: Taner ve Taner 1948.

plan çalışması yapıldığı, ancak, imar planları nüfus hedeflerinin, güncel mekânsal gelişme eğilimleri ile nüfus gelişme dinamiklerinin gerisinde kaldığı ve sürekli revizyon çalışmalarına konu edildiği ifade edilmelidir (Orhan ve Maden, 2003: 105106). Nitekim 1972 Revizyon İmar Planı Açıklama Raporu içeriğinde, kentte yaklaşık 35.000 gecekondu nüfusu olduğuna ilişkin tespitler, plansız-denetimsiz gelişmenin sosyo-mekânsal boyutlarını göstermesi bakımından önemlidir (Anonim, 1972; Anonim, 1976).

\section{SOSYALANALIZ: Kentleşme Niteliği ve Nüfus Dinamikleri}

Kırıkkale'nin kentleşme süreci irdelenirse; herhangi bir yerleşim kökeni/mirası olmaksızın, askeri fabrikalar ile sınırlı sayıda lojman-memur konutları kurulması ile geliştiği ifade edilmelidir. Bu açıdan bakılırsa, askeri fabrikaların kurulması ve istihdam potansiyeline dayalı nüfus hareketleri, Kırıkkale'nin kuruluş-gelişim süreci bağlamında kentleşme dinamikleri ve yerleşim sürecini yönlendiren temel dinamik olarak kabul edilmelidir.
Başka bir ifadeyle, sanayi çekim gücü esas olmak üzere göç hareketleri eşliğinde kurulması-gelişmesi bakımından Kırıkkale'nin "kendine özgü" bir kentleşme sürecine konu olduğunu söylemek mümkündür. Nitekim nüfus gelişim süreci irdelenirse, yakın çevre kırsal alanların yanısıra, yakın etki alanındaki Kalecik, Keskin ve Delice gibi ilçe merkezleri ile yakın bölgesindeki Yozgat, Çorum ve Kırşehir gibi il merkezlerinden aldığ "göç hareketleri" ve "sanayi istihdamı" bağlamında aşırı nüfus artışına dayanan bir kentleşme karakteri gösterdiği anlaşılmaktadır (Aydoğan, 219-250; Kunter, 1961: 9-12; Yücel, 1961: 31-44).

Kırıkkale'nin kuruluş dönemindeki nüfus yapısı ve bileşenleri irdelenirse; devlet eliyle görevlendirilen teknik elemanlar, memurlar ve asker işçiler ile yakın-uzak çevre yerleşmelerden istihdam için gelen sivil işçilerden oluştuğunu söylemek mümkündür (Atalay, 1983: 78). Bu noktada, kuruluş dönemine tarihlenen gezi anlatılarında, “...Siyah giymiş hocalar, iş gömlekli işçiler, ustalar, mühendisler, bereli kadınlar, irili ufakl çocuklar...", devamla, “...Kırıkkale; bozkırın ortasında baca, 

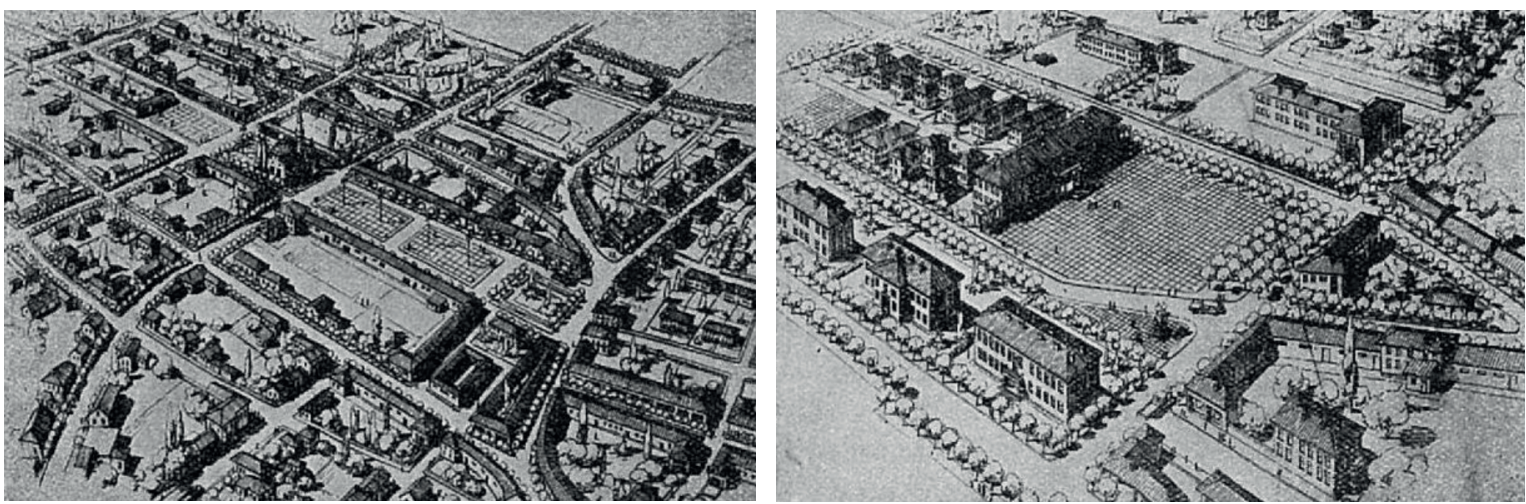

Şekil 7: Kırıkkale kenti ilk imar planı; kent merkezi tasarımı.

Figure 7: The First Development Plan for Kırıkkale City, The Design of City Center.

Kaynak: Taner ve Taner 1948.

fabrika, asfalt, hendese, boyall ev, sağlam tavan, iş gömleği giyen alın terli insan demektir... " biçimindeki ifadeler, Kırıkkale nüfusunun temel bileşenlerinin işçi, mühendis, memurlardan oluştuğunu doğrular niteliktedir (Etem,1934: 76-78).

Benzer biçimde, askeri fabrikalarının kuruluş sürecine ilişkin hatırat yazılarında; “...1932 yllında askeri fabrika sahası dışında sadece $13 \mathrm{ev}$ vardl. Meyhane, kahvehane ve kasap dükkânı ayn yerdi. Yol yoktu. Haftada bir tren geçerdi. Gazete gelmezdi. Fabrikaya trenler ya da çamur tarlalardan geçerek gidilirdi. İş̧̧ hemen tamamen yörenin köylüsüydü. İki üç saatte köyünden eşekle veya yaya gelirdi. Fabrikada eşeklere ayrı yer vardl..." biçimindeki söylemler, fabrika yerleşkesi çevresinde yerleşim alanları olmadığını, istihdamın ise günübirlik geliş-gidişler bağlamında tamamen kırsal karakterli nüfusa dayandığına işaret etmektedir. $\mathrm{Bu}$ yönüyle, Kırıkkale'nin mekânsal kuruluş sürecinde sosyal ve teknik altyapı bakımından kentsel nitelik taşımayan tamamen üretim odaklı bir sanayi yerleşkesi niteliğinde olduğu söylenebilir (Kuruş, 1998: 3-9).

Ancak, Kırıkkale sanayi yerleşkesinin kuruluşundan yaklaşı on beş yıl sonrasına, 1948 yılına tarihlenen gazete arşivlerinde; “...adeta küçük bir sanayi merkezi, bir iş̧̧iler yurdu mahiyetinde bulunan Kırlkkale, medeni ihtiyaçları tatmin edebilecek vasitalara sahip olmak bakımından memleketin birçok kaza merkezlerinden daha ileri bir vaziyette bulunuyor ... "biçimindeki ifadeler, Kırıkkale'nin kentleşme sürecinde gösterdiği gelişmenin sosyo-mekânsal boyutlarını ortaya koyması bakımından önemlidir (Köprülü, 1948).

Kırıkkale'nin sosyo-kültürel yapısı ve değişim süreci irdelenirse; kentsel nüfusun yakın çevre kırsal ve kentsel alanlardan gelenler ile uzak bölgelerden gelenler olmak üzere 2 (iki) kategoride değerlendirildiği görülmektedir (Atalay, 1983:
90-95; Erbaş, 1993: 109-111). Bu açıdan bakılırsa, Kırıkkale'nin göçe dayalı kentleşme karakterinin, kırsal kimlik veya farklı kentsel aidiyetler bağlamında hemşehrilik bağlarının gelişmesinde etkili olduğu düşünülebilir. Nitekim kentlilik bilinci ve aidiyet üzerine yapılan bir araştırmalar,-Keskinliler, Deliceliler, Obalılar, Çorumlular, Kırş̧ehirliler, Yozgatlllar gibi-kültür ve yardımlaşma derneklerinin yoğunluğunu, "göçe dayalı kentleşme karakterinin" sonucu olduğuna dikkat çekmektedir (Tezcan 1991: 315-333, Çekirge, 2013; Duman, 2013; Yıldırım, 2010).

Öte yandan, Kırıkkale hemşehri dernekleri üzerine yapılan bir araştırmada; faal hemşehri derneklerinin Türkiye ortalaması üzerinde olması, Kırıkkale'nin göç dayalı kentleşme sürecinde kurulmuş-gelişmiş olmasının doğal sonucu olarak değerlendirilmektedir (Kurtbeyoğlu, 2005: 144-146). Ancak, aynı araştırmada hemşehri derneklerinin kente gelenlerin uyumuna yönelik değil, tersine kente gelenlerin ayrışarak, dayanışma-birliktelik kurmalarına yönelik faaliyet gösterdiğine ilişkin tespitler, kentlilik bilincinin gelişmesi ve kent aidiyetinin oluşması bakımından önemli bir sorun olarak kaydedilmektedir (Kurtbeyoğlu, 2005: 144-146).

Benzer biçimde, Kırıkkale'nin kentleşmesi üzerine sosyolojik araştırmalarda, kentsel mekânların/mahallelerin sosyo-mekânsal örgütlenmesinde -Kayserililer Mahallesi gibi- hemşehrilik bağlarının belirleyici olduğu, bu durumun, kentsel nüfusun bütünleşme ve kimlik-aidiyet sorunlarına neden olduğu ifade edilmektedir (Atalay, 1983: 121-123; Tezcan, 1991: 329-330). Bu tespitler, Kirıkkale'de kentsel aidiyet -Kırıkkaleli olma kimliği- ve sosyo-mekânsal bütünleşme bağlamında yaşanan sorunlarının, "göçe dayalı kentleşme karakterinin" sonucu olduğunu göstermektedir (Batmaz ve Gürer, 2016: 163-177; Şahin ve Anık 216: 151172; Şahin ve Yayl1, 2016: 79-18). 
Kırıkkale'nin nüfus gelişim süreci incelenirse; sanayileşmekentleşme etkileşimi bağlamında nüfus dinamikleri açısından 3 (üç) kırılma noktası olduğu söylenebilir.

Birincisi; 1945 yılında yaklaşı 14.000 olan nüfusun, on yıl içinde iki kat artış ile 1955 yılında yaklaşık 27.000 nüfusa ulaşmasıdır (Aydoğan, 1971: 54). Bu artışın sebebini, Makine Kimya Endüstrisi Kurumu'na devredilen sanayi tesislerinin artan işgücü gereksinimlerine dayalı olarak Kırıkkale'nin cazibe merkezi niteliği kazanmasına dayandırmak mümkündür.

İkincisi; 1975-1985 döneminde ise Kırıkkale kent nüfusunun orta ölçekli kentler için nüfus eşiği olarak ifade edilen 100.000 kriterini aşmasıdır. Bu süreçte, Kırıkkale kentinin 1975'de yaklaşık 140.000 nüfus, 1980 yılında ise yaklaşık \%30 artış ile 180.000 nüfusa, $1985^{\prime}$ de ise yaklaşı 200.000 nüfusa ulaştı̆̆ görülmektedir. Nitekim Türkiye'nin kentleşme ve nüfus gelişim süreci üzerine araştırmalar, 1975-1985 dönemini yaklaşı 50.000 üzerinde nüfus artışı ile Kırıkkale'nin en yoğun nüfus gelişme dönemi olarak kaydetmektedir. Bu süreçte; İç Anadolu Bölgesi'nin önemli kentsel merkezleri arasında sayılan Kırıkkale, doğuda Kayseri, batıda Eskişehir kentleri ile birlikte başkent Ankara üzerindeki nüfus gelişim baskısını çekebilecek nitelikte ön merkezler arasında sayılmaktadır (Henden, 1992: 48-61; Avc1, 1993: 249-269; Karacaoğlu, 1982: 60; Işık, 2005: 57-71; Yıldırım, 2010: 86-87).

Üçüncüsü ise 1990-1995 döneminde nüfus gelişiminde ilk kez azalma olmasıdır. Bu azalmanın sebeplerini, Makine Kimya Endüstrisi (MKE) Silah Fabrikaları istihdam kısıtlamaları ve erken emeklilik olanakları eşliğinde yakın erişilebilir konumdaki Ankara kentine göç hareketleri ilişkilendirmek mümkündür (Y1ldırım, 2010: 140-144). Nitekim 1965-2000 döneminde Türkiye bütününde iç göçler üzerine yapılan demografi araştırmasında, Kırıkkale kentinin yaklaşık 14.000 göç nüfusu ile başkent Ankara'ya en çok göç veren iller sıralamasında ilk beş il arasında olduğu görülmektedir (Kocaman, 2008).

$\mathrm{Bu}$ dış göç olgusunun temel sebebi, askeri sanayi odaklı istihdamın azaltılmasına yönelik politikalar ile ilişkilendirilebilir. Ancak, arka planda kentsel gelişme sürecinin askeri sanayi ve idari hizmetler başta olmak üzere devlet eliyle yönlendirilmesine karş11ı, sanayi sektörü ile hizmet sektörü dengesinin kurulamaması, özellikle kent ekonomisi-ticaret alanında yeterli sermaye birikimi ve gelişme dinamiklerinin sağlanamaması olarak görülmelidir. Nitekim Türkiye'de imalat sanayisinde uzmanlaşmış kentsel yerleşmeler üzerine yapılan bir araştırmada; Orta Anadolu Bölgesi'nde Kırıkkale gibi devlet destekli kurulan sanayilere dayalı imalat kentlerinin, hizmet sektöründe yeterli gelişme göstermediği, bu yönüyle, uzmanlaşma yeteneklerini de kaydettikleri ya da başka kentlere devrettikleri kaydedilmektedir (Bayar ve Diğerleri, 2003: 1-12).

Ancak, 1989 yılında "İl statüsü" kazanması ile Kırıkkale kentinin sektörel bağlamda -özellikle hizmet sektörü- yeniden yapılanma sürecine girdiği söylenebilir (Esirci, 1991: 44-45). $\mathrm{Bu}$ sürecin nüfus gelişimi üzerindeki etkisinin, 1990-1995 döneminde nüfus gerileme-azalma eğilimlerinin, 2000 yılından itibaren durağanlaşma eğilimine dönüşmesi biçiminde olduğu anlaşılmaktadır. Nitekim Türkiye İstatistik Kurumu (TÜIK) nüfus verileri irdelenirse; son on ylllık süreçte (2007-2017 döneminde) Kırıkkale nüfusunun 192.000-194.000 aralığında durağan eğilim gösterdiği görülmektedir.

\section{SONUÇ}

Cumhuriyetin kuruluş sürecinde ulusal kalkınma çabalarına dönük olarak üretilen öncelikli sanayi politikalarının yansıması olarak kurulan-gelişen stratejik sanayi kenti işlevindeki Kırıkkale kentinin, tarihsel geçmiş, mekânsal arka plan, planlama deneyimleri ve sosyal dinamikler açısından ele alınarak değerlendirilmesi ile mekânsal gelişme sorun-potansiyelleri ile sosyal gelişme dinamikleri bağlamında ulaşılan sonuçlar, 4 (dört) başlık altında derlenmiştir:

1- Kırıkkale kentinin askeri fabrikalar ve destek tesislerinden (sosyal tesis-lojman vb.) oluşan planlı sanayi yerleşkesi niteliğindeki mekânsal kuruluş sürecinin, istihdam kapasitesi artışına koşut hızlı nüfus artışına dayalı plansız-denetimsiz mekânsal gelişme sürecine evrildiği belirlenmiştir. Nitekim sözkonusu süreçte Kırıkkale kentinin "büyümüş köy olarak adlandırıldığı görülmektedir. Bu durumu, hızlı nüfus artışına koşut mekânsal gelişme sürecinde kentsel sosyo-kültürel ve teknik altyapı gereksinimlerinin karşılanmasına yönelik hizmet kurumu niteliğindeki belediye teşkilatının kurulmamış olması ile ilişkilendirmek mümkündür. Nitekim belediye teşkilatının kurulması, yerleşkenin kurulmasından yaklaşık on beş yıl sonrasına tarihlenmektedir. $\mathrm{Bu}$ tespitler, kentleşme sürecinde nüfusun gereksinim duyduğu sosyal-kültürel ve teknik altyapı hizmetlerinin yerinde karşılanması, sosyo-mekânsal gelişim sürecinin denetlenmesi-yönlendirilmesi ve planlı kentleşme sürecinde yerel yönetimlerin önem ve gerekliliğini ortaya koymaktadır.

2- Kırıkkale kenti gibi belirli ve tanımlı bir kentsel yerleşim kökenine sahip olmadan -otonom yatırım ve yer seçimi kararlarına dayalı olarak- kurulan-gelişen kentlerin, geleceğe 
yönelik sosyo-mekânsal ve ekonomik gelişim süreci ve aşamalarının tanımlanması, planlı kentsel gelişme sağlanması ve nüfus dinamikleri denetimi açısından temel öncelik olarak görülmelidir. Bu yönüyle bakılırsa, geleceğe yönelik mekânsal karakteristik, sektörel/işlevsel kimlik ve demografik kapasiteyi tanımlayan kentsel senaryo/vizyon eksikliğinin, Kırıkkale örneğinde plansız-denetimsiz sosyo-mekânsal gelişmeler olarak somutlaştığını söylemek mümkündür. Bu durum, göçe dayalı kentleşme sürecinde özellikle istihdam kapasitesipotansiyeli bağlamında cazibe ve çekim merkezi niteliği kazanan sanayi kentleri için "sosyo-ekonomik yaşama yönelik kestirimlerin" gerekliliğine vurgu yapması bakımından öğreticidir.

3- Kırıkkale kenti örneğinde ortaya çıan bir başka sonuç; mekânsal ve işlevsel gelişme sürecine ilişkin planlama deneyimlerinin, sanayileşme sürecine koşut mekânsal talepler bağlamında nüfus gelişme dinamiklerinin gerisinde kalmasıdır. Nitekim 1948 y1lına tarihlenen ilk bütüncül plan dışında tüm imar planlarının "Revizyon Planı" olarak yapıldığı görülmektedir. Dolayısıyla, sanayileşme-kentleşme etkileşimi bağlamında ortaya çıkan planlama sorunlarının, sektörel ve demografik içerik ele alınmadan, güncel sorun odaklı parçacı mekânsal kararlara dayanan planlama deneyimleri ile çözümlendiği anlaşılmaktadır. Bu durum, planlı-denetimli ve sağlıklı kentsel gelişme için "kent bütününe yönelik senaryo bağlamında uzun erimli mekânsal, sektörel ve demografik kestirimlerin birlikteliğine dayanan planlama pratiğinin" temel koşul olduğunu göstermesi bakımından önemlidir.

4- Sanayi yerleşkesinin kurulması ile başlayan kentsel gelişme sürecinde Anadolu'nun farklı bölgelerinden kırsal ve kentsel nüfusun yerleşmesi ile gelişen Kırıkkale kentinin, çok kültürlü bir demografik yapıya sahip olduğu belirlenmiştir. Nitekim Kırıkkale kentinde faal hemşehri derneklerinin Türkiye ortalamasının üzerinde olduğuna ilişkin tespitler, göçe dayalı kentleşme göstergesi olarak kent kimliği ve aidiyet duygusunun yeterince gelişmediğini göstermektedir. $\mathrm{Bu}$ durum, sanayi istihdamı odaklı göç olgusuna dayalı olarak kurulan-gelişen Kırıkkale kenti örneğinde sosyo-mekânsal bağlamda bütünleşme sorunlarına neden olmuştur. Dolayısıyla, Kırıkkale örneğinde somutlaşan istihdam odaklı göçe dayalı kentleşme karakteri bağlamında göç ile gelen nüfusun kentsel yaşam ile bütünleşmesi ve kentsel aidiyet/kimlik duygusunun geliş(tiril)mesi için "kursal yaşam pratiklerinin, kentsel yaşam dinamikleri ile bütünleştirilmesine" yönelik sosyo-kültürel içerikli planlama pratiklerinin önem ve gerekliliğine işaret sayılmalıdır.
Araştırma kapsamında Cumhuriyetin sanayi kenti olarak kurulan-gelişen Kırıkkale örneğinden çıkarılan derslerin, sanayileşme-kentleşme sürecinde mekânsal, sektörel ve demografik etkilere yönelik kestirimlerin önem ve gerekliliğine ilişkin tespitler bağlamında kentleşme dinamikleri ve yerleşme politikaları açısından yerel ve merkezi yönetim karar alma-karar verme süreçlerine katk1 sunacağı düşünülmektedir.

Hakem Değerlendirmesi: Dış bağımsız.

Çıkar Çatışması: Yazar çıkar çatışması bildirmemiştir.

Finansal Destek: Yazar bu çalışma için finansal destek almadığını beyan etmiştir

Peer-review: Externally peer-reviewed.

Conflict of Interest: The author has no conflict of interest to declare.

Grant Support: The author declared that this study has received no financial support.

\section{KAYNAKÇA/REFERENCE}

İnan, A. (1972). Devletçilik ilkesi ve Türkiye Cumhuriyeti'nin birinci sanayi plant-1933. Ankara: Türk Tarih Kurumu Yayınları.

İnan, A. (1973). Türkiye Cumhuriyeti'nin ikinci sanayi planı-1936. Ankara: Türk Tarih Kurumu Yayınları.

İnan, A. (1989). İzmir iktisat kongresi. Ankara: Türk Tarih Kurumu Yayınları.

Anonim (1940). Askerifabrikalar tarihçesi. (Eyüp Durukan, hazırlatan). Ankara: Askeri Fabrikalar Basımevi.

Anonim (1948). Kırıkkale imar planı ve izah notu. Mimarlk, 1, 19-22.

Anonim (1972). Kırıkkale ana imar planı açıklama notu. (Yayımlanmamış rapor). Kırıkkale Belediyesi Arşivi.

Anonim (1975). Türk İstiklal Harbi VII. cilt: idari faaliyetler (15 Mayls 1919-2 Kasım 1920). Ankara: Genelkurmay Basımevi.

Anonim (1976). Kırıkkale şehri tatbikat planları açıklama raporu. (Yayımlanmamış rapor). Kırıkkale Belediyesi Arşivi.

Arıkan, Y., Akkaş, Ö.P. ve Çam, E. (2018). Kırıkkale ili hafif raylı sistem etüdünün gerçekleştirilmesi. Uluslararası Mühendislik Araştırma ve Geliştirme Dergisi, 10(3), 6-11.

Aslıÿ̈ce, E. (1974). Her yönüyle Kırıkkale. Kırıkkale: Kırıkkale Kalkındırma ve Güzelleştirme Derneği Yayınları.

Atalay, B. (1983) Sanayileşme ve sosyal değişme (Kırıkkale araştırması). Ankara: Devlet Planlama Teşkilatı Yayınları.

Avc1, S. (1993). Türkiye'de şehir ve şehirli nüfusun dağıllş̧ (19271990). Türk Coğrafya Dergisi, 28, 249-269.

Ay, E. (1995). Arkeolojik araştırmalar ışığında Kırıkkale'nin eskiçağ tarihine kısa bir bakış, Kırıkkale Dergisi, 2, 31-38.

Aydoğan, K. (1963). Kızılırmak doğusunda Ankara'nın üç ilçe merkezi. Türk Coğrafya Dergisi, 22-23, 169-185.

Aydoğan, K. (1968). Mevzii coğrafya yönünden Kırıkkale-Delice ve Keskin. Ankara Üniversitesi Coğrafya Araştırmaları Dergisi, 2, 219-250. 
Aydoğan, K. (1971). Mevzii coğrafya yönünden Kırıkkale, Keskin ve Delice II. Ankara Üniversitesi Coğrafya Araştırmaları Dergisi, 3-4, 53-94.

Balkan, Y. (2014). Kırıkkale eğitim tarihi (1923-2014). (Yayımlanmamış yüksek lisans tezi). Atatürk Üniversitesi/Eğitim Bilimleri Enstitüsü, Erzurum.

Batmaz, N.Y. ve Gürer, A. (2016). Kırıkkale ilinin kentlilik bilinci bağlamında değerlendirilmesi üzerine bir araştırma. Yusuf Şahin, Oğuzhan Aslantürk, Vildan Armağan (Editörler), 4. Uluslararası Kentsel ve Çevresel Sorunlar ve Politikalar Kongresi içinde (s.163177). İstanbul.

Bayar, R., Yüceşahin, M.M. ve Özgür, E.M. (2003). Türkiye'nin imalât işlevinde uzmanlaşmış şehirsel yerleşmeleri. Coğrafi Bilimler Dergisi 1 (2), 1-12.

Çekirge, S. (2013). Sanayileşmenin kentleşmeye etkisi, Kırıkkale örneği. (Yayımlanmamış yüksek lisans tezi). Kırıkkale Üniversitesi/Sosyal Bilimler Enstitüsü, Kırıkkale

Çiçek, P. (2018). Orta Kızılırmak Havzası'nın demir çă̆ı. (Yayımlanmamış yüksek lisans tezi). Ahi Evran Üniversitesi/Sosyal Bilimler Enstitüsü, Kırşehir.

Doğan, M (2013). Türkiye sanayileşme sürecine genel bir bakış. Marmara Coğrafya Dergisi 28, 211-231.

Doğan, B. ve Kablan, A. (2016). Kırıkkale şehir içi ulaşımda alternatif sistem değerlendirmesi. Düzce Üniversitesi Bilim ve Teknoloji Dergisi 4, 431-437.

Duman, M. (2013). Türkiye'de sanayi ile birlikte doğan kentlerde kentleşme ve kimlik problemi (Kırıkkale örneği). (Yayımlanmamış yüksek lisans tezi). Kırıkkale Üniversitesi/Sosyal Bilimler Enstitüsü, Kırıkkale.

Erbaş, H. (1993). Class and culture: the cases of Kırıkale and Ankara. (Yayımlanmamış doktora tezi). Ortadoğu Teknik Üniversitesi/ Sosyal Bilimler Enstitüsü, Ankara.

Erdoğan, R.S. (1999). Kırıkkale ili coğrafyası. (Yayımlanmamış yüksek lisans tezi). Ankara Üniversitesi/Sosyal Bilimler Enstitüsü, Ankara.

Esirci, N. (1991). Taşra teşkilatlarının örgütlenmesinde yeni il ve ilçeler, Kırıkkale örneği. (Yayımlanmamış yüksek lisans tezi). İstanbul Üniversitesi/Sosyal Bilimler Enstitüsü, İstanbul.

Etem, S. (1934). Kiyllardan stepe bir vagon penceresinden. XII Kırıkkaleye giderken, İstanbul: Kanaat Kütüphanesi Yayınları.

Evliya Çelebi (2006). Günümüz Türkçesiyle Evliya Çelebi seyahatnamesi. Yücel Dağlı ve Seyit Ali Kahraman (Editörler), 2. Kitap-2. Cilt, İstanbul: Yapı Kredi Yayınları.

Evsile, M. (1992). Atatürk devri harp sanayii (1920-1938). (Yayımlanmamış doktora tezi). Fırat Üniversitesi/Sosyal Bilimler Enstitüsü, Elazığ.

Gülyazı, Y. (2004). Kırıkkale şehir coğrafyası. (Yayımlanmamış yüksek lisans tezi). Ondokuz Mayıs Üniversitesi/Sosyal Bilimler Enstitüsü, Samsun.

Güner, İ. ve Ertürk, M. (2004). Türkiye İl Merkezi Kent Adlarının Kaynakları Üzerine Bir Araştırma. Muğla Üniversitesi Sosyal Bilimler Enstitüsü Dergisi, 12, 39-62.
Hanc1, M. (1945). Kırıkkale kazası (coğrafi monografyası). (Yayımlanmamış mezuniyet tezi). İstanbul Üniversitesi/Coğrafya Enstitüsü, İstanbul.

Henden, E. (1992). Türkiye'de şehirleşme hareketlerinin iller bazında incelenmesi. (Yayımlanmamış yüksek lisans tezi). İstanbul Üniversitesi/Sosyal Bilimler Enstitüsü, İstanbul.

Işık, Ş. (2005). Türkiye'de kentleşme ve kentleşme modelleri. Ege Coğrafya Dergisi, 14, 57-71.

Iş1k, Ş. (2008). Türkiye'deki üniversitelerin kentleşme üzerindeki etkileri. Dokuz Eylül Üniversitesi Sosyal Bilimler Enstitüsü Dergisi, 10(3), 159-181.

Kankal, A. (1998). Kırıkkale tarihine dair araştırmalar I: iskân. Osmanlı Tarih Araştırmaları (OTAM) Dergisi, 9, 225-239.

Karacaoğlu, A. (1982). 1975-1980 yılları arasında Türkiye'de nüfus artışının ilçelere göre durumu. (Yayımlanmamış Mezuniyet Tezi). İstanbul Üniversitesi/Coğrafya Enstitüsü, İstanbul.

Karadeniz, E. (2006). Kırıkkale'de şehirsel gelişme. (Yayımlanmamış yüksek lisans tezi). Ankara Üniversitesi/Sosyal Bilimler Enstitüsü, Ankara.

Karatay, A. (2017). Bir fabrika-kentin sosyal ve siyasal tarihi: Karabük ve KDÇF 1937-1995. (Yayımlanmamış yüksek lisans tezi). Karabük Üniversitesi/Sosyal Bilimler Enstitüsü, Karabük.

Kaynar, İ.S. (2017). Ankara'nın iktisadi değişimi ve başkent olma süreci. İsmail Şiriner, Şevket Alper Koç, H. Yıldız (Editörler), Current Debates in Economics and Econometrics içinde (s.179200). 2, Baltimore: IJOPEC Publication Limited.

Kıraç, D. (2018). Cumhuriyet Halk Partisi Kırıkkale teşkilatı (1940 1950). (Yayımlanmamış yüksek lisans tezi). Kırıkkale Üniversitesi/ Sosyal Bilimler Enstitüsü, Kırıkkale.

Kizmaz, E. (2007). Turkish defense industry and undersecretariat for defense industries. (Yayımlanmamış yükssek lisans tezi). Bilkent Üniversitesi/Sosyal ve Ekonomik Bilimler Enstitüsü, Ankara.

Kocaman, T. (2008). Türkiye'de iç göçler ve göç edenlerin nitelikleri (1965-2000). Ankara: Devlet Planlama Teşkilatı Yayınları.

Köprülü, M.F. (1948, 5 Şubat). Kırıkkale ve Keskin'den intibalar. Kudret: Günlük Siyasi Demokrat Gazete, 1, 173.

Kunter, Ü. (1961). Kırıkkale nasıl teşekkül ediyor. Bilgi, 15 (176-177), 9-12.

Kurtbeyoğlu, T. (2005). Kırıkkale il merkezinde faaliyet gösteren hemşehri dernekleri ve bu derneklerin ilin sosyal, kültürel ve siyasal yapısına etkileri. (Yayımlanmamış yüksek lisans tezi). Kırıkkale Üniversitesi/Sosyal Bilimler Enstitüsü, Kırıkkale.

Kuruş, B. (1998). Selahaddin Beyin öyküsü: isteseler herşey yapılabilirdi. Mahmut Kiper (Editör), Paydossuz bir yaşam: 19071995 içinde (s.3-9). Ankara: TMMOB Metalürji Mühendisleri Odas1 Yayınları.

Metin, R. (1997). Osmanlı arşiv belgelerine göre XVI. yüzyılda Kırlkkale il bölgesi (Keskin, Konur, Dinek nahiyeleri). (Yayımlanmamış yüksek lisans tezi). Kırıkkale Üniversitesi/Sosyal Bilimler Enstitüsü, Kırıkkale. 
Metin, R. (2007). XVI. yüzyılda Orta Anadolu'da nüfus ve yerleşme (Bozok, Kirşehir, Niğde, Nevşehir ve Keskin örneği). (Yayımlanmamış doktora tezi). Gazi Üniversitesi/Sosyal Bilimler Enstitüsü, Ankara.

Oğuz, A. (2006). Kırıkkale'nin kuruluşunda silah sanayinin rolü. (Yayımlanmamış yüksek lisans tezi). Kırıkkale Üniversitesi/Sosyal Bilimler Enstitüsü, Kırıkkale.

Orhan, T. ve Maden Ş. (2003). Kırıkkale'de yerel yönetim. Hakan Arslan ve Adnan Vural Örsdemir (Editörler), 21. Yüzyılın Başında Kırıkkale Sempozyumu içinde (s.105-106). Ankara: Çelik-İş Sendikası Yayınları.

Öktem, S. (2004). Türkiye Cumhuriyeti nde modernleşme hareketi; Karabük demir çelik fabrikaları yerleşim örneği. (Yayımlanmamış yüksek lisans tezi). İstanbul Teknik Üniversitesi/Fen Bilimleri Enstitüsü, İstanbul.

Örkçüoğlu, M. (1990). İlçemiz Kırıkkale, Ankara: Örkçüoğlu Yayınları.

Özgür, D. (2019). Kırıkkale'de Türk devri eserleri. (Yayımlanmamış yüksek lisans tezi). Gazi Üniversitesi/Sosyal Bilimler Enstitüsü, Ankara.

Özlü, H. (2006). II. Dünya Savaşı'ndan günümüze Türkiye'de savunma sanayinin gelişimi (1939-1990). (Yayımlanmamış doktora tezi). Dokuz Eylül Üniversitesi/Atatürk İlkeleri ve İnkılap Tarihi Enstitüsü, İzmir.

Pehlivanl1, H. (2008). Kırıkkale halkevi (1942-1951). Atatürk Araştırma Merkezi Dergisi, XXIV (70), 127-147.

Pehlivanlı, M. (1986). Kırıkkale çevre araştırması. Ankara: Cemiloğlu Yayınlar1.

Pekgöz, İ. (2002). Kırıkkale il coğrafyasındaki (XVI-XVIII. yüzyıllarda Dinek, Keskin ve Konur kazalarında) aşiretler. (Yayımlanmamış yüksek lisans tezi). Kırıkkale Üniversitesi/Sosyal Bilimler Enstitüsü, Kırıkkale.

Przeworski, S. (1929). Studja nad osadnictwem I rola hetytów w środkowej Anatolji. Agrikola, 9, Warshawa: Państwowe muzeum archeologiczne.

Sezgin, İ. (2009). 1923-1939 yılları arasında Türk ordusunda yapılan askeri yatırımlar. (Yayımlanmamış yüksek lisans tezi). İnönü Üniversitesi/Sosyal Bilimler Enstitüsü, Malatya.

Şahin K. ve Anık, M. (2016). Göç, kentleşme ve kentlilik bilinci: Kırıkkale örneği. Zeitschrift Für Die Welt Der Türken (ZfWT), 8 (3), $151-172$.

Şahin, K. ve Yaylı, H. (2016). Geleneksel göçebelikten modern göçlere Türkiye'de gençlerin kentlilik bilinci; Kırıkkale örneği üzerinden bir analiz. Üçüncü Sektör Sosyal Ekonomi, 51 (2), 79-108.

Taner, N. ve Taner, P. (1948). Kırıkkale şehri. Arkitekt, 195-196, 72-75. Tekalp, C., Utlu, V., Sözer, F.D., Sürücü, E., ve Duru, D. (2017). Hüseyin Kâhya Hiçyılmaz ve Kırıkkale’nin Gelişimi. (Yayımlanmamış öğrenci projesi), Bilkent Üniversitesi, Ankara.
Tekeli, İ. ve Ortaylı, İ. (1987). Türkiye'de belediyeciliğin evrimi. 1. Kitap, Ankara: Türk İdareciler Derneği Yayınları.

Tezcan, M. (1991). Sanayileşme sürecinde halk kültürü ve Kırıkkale örneği. Eğitim Bilimleri Dergisi 24 (2), 315-333.

Tuncel, M. (1981). Tarih boyunca Türkiye'de kent kuruluşları, Doğumunun 100. Yılında Atatürk'e Armă̆an (s.309-351), İstanbul: İstanbul Üniversitesi Yayınları.

Tuncel, M. (2002). Kırıkkale. Türkiye Diyanet Vakfi Íslam Ansiklopedisi, (Cilt: 25, s.446-447), Ankara: Türkiye Diyanet Vakfı Yayınları.

Tümertekin, E. (1959). Türkiye sanayiinin coğrafi temelleri. Türk Coğrafya Dergisi, 18-19, 16-54.

Von Der Osten, H.H. (1927). The ancient settlement at Kürigin Kaleh in Asia Minor. The American Journal of Semitic Languages and Literatures, 43 (4), 288-294.

Von Der Osten, H.H. (1927a). Explorations in Central Anatolia season of 1926. Chicago: The University of Chicago Press.

Von Der Osten, H.H. (1930). Explorations in Hittite Asia Minor. Chicago: The University of Chicago Press.

Vural, E. (2018). Kırıkkale şehrinin Cumhuriyetten günümüze mekânsal gelişimi. (Yayımlanmamış yüksek lisans tezi). İstanbul Üniversitesi/ Sosyal Bilimler Enstitüsü, İstanbul.

Yassı, N.T. (2000). Gölcük şehir coğrafyası. (Yayımlanmamış yüksek lisans tezi). Marmara Üniversitesi/Sosyal Bilimler Enstitüsü, İstanbul.

Yıldırım, D. (2010). Kırıkkale ve göç. (Yayımlanmamış yüksek lisans tezi). Kırıkkale Üniversitesi/Sosyal Bilimler Enstitüsü, Kırıkkale.

Yıldırım, M. (1966). Tarihte Kırıkkale. Ankara: Öğretmenler Matbaası.

Yıldırım, Ö. (1991). Garnizon şehri Gölcük. (Yayımlanmamış yüksek lisans tezi). İstanbul Üniversitesi/Sosyal Bilimler Enstitüsü, İstanbul.

Yılmazer, D. (2018). Cumhuriyet dönemi milli savunma sanayiinin kurulması ve ordunun yenileştirilmesi politikaları. (Yayımlanmamış yüksek lisans tezi). Ufuk Üniversitesi/Sosyal Bilimler Enstitüsü, Ankara.

Yurtoğlu, N. (2017). Türk savunma sanayiinde girişimci bir kuruluş: Makine ve Kimya Endüstrisi Kurumu (MKEK) 1950-1960. Yakın Dönem Türkiye Araştırmaları, 16 (31), 81-112.

Yücel, M. (1959). Kırıkkale fabrikalarının kuruluşu. MKE Haberleri, $49,3$.

Yücel, T.F. (2015). Cumhuriyet Türkiyesi'nin sanayileşme öyküsü. Ankara: Türkiye Teknoloji Geliştirme Vakfı Yayınları.

Yücel, T. (1961). Türkiye'de şehirleşme hareketleri ve şehirler. Türk Coğrafya Dergisi, 21, 31-44.

Zengin, E. (2017). Milli mücadele yıllarında İmalat-1 Harbiye Fabrikalar1. Mavi Atlas, 5(1), 201-223. 